\title{
Inference model to predict heavy metals of Bahr El Baqar soils, Egypt using spectroscopy and chemometrics technique
}

\author{
El-Sayed E. Omran ${ }^{1}$
}

Received: 30 October 2016/Accepted: 2 November 2016/Published online: 11 November 2016

(C) Springer International Publishing Switzerland 2016

\begin{abstract}
With 35 soil samples gathered from the Bahr El Baqar region, Egypt, the objective of this study was to propose an inference model for prediction of heavy metals $(\mathrm{Cd}$, $\mathrm{Cu}, \mathrm{Pb}, \mathrm{Zn}, \mathrm{Ni}, \mathrm{Mn}, \mathrm{Cr}, \mathrm{Co}, \mathrm{Fe}$ ) with visible near-infrared and short wave infrared (VNIR-SWIR) region (350-2500 nm). For a better understanding of the mechanism that allows the estimation of heavy metals with reflectance spectroscopy, statistical analysis was first made. The fingerprint region of $538,578,630,870,1900,2240$, and $2376 \mathrm{~nm}$ is very useful in recognizing small differences in the heavy metals of Bahr El Baqar region. Partial least squares regression (PLSR) is able to some extent (moderate accuracy) to model heavy metals with laboratory spectra parameters. The best coefficients of determination $\left(R^{2}\right)$ between predicted and chemically analyzed concentrations were for $\mathrm{Mn}, 0.62 ; \mathrm{Pb}, 0.66$; $\mathrm{Zn}, 0.66, \mathrm{Ni}, 0.69$, and $\mathrm{Cu}, 0.60$. Iron influences the soil reflectance in the VNIR-SWIR region. This is due to the electronic transition of iron cations $(2+, 3+) . \mathrm{Mn}, \mathrm{Pb}, \mathrm{Ni}$, $\mathrm{Cu}$, and $\mathrm{Zn}$ were successfully predicted using PLSR. Only $\mathrm{Cr}$ (0.59) and $\mathrm{Cd}(0.52)$ content was predicted fairly. The analysis of correlation between heavy metal and soil constitutes of $\mathrm{Fe}_{2} \mathrm{O}_{3}, \mathrm{Al}_{2} \mathrm{O}_{3}$ and $\mathrm{OM}$, which represented the clay minerals, iron oxides and organic matter, respectively, could support the above predicated binding forms of heavy metals. The order of the correlation coefficients from high to low between metal and wavelength is $\mathrm{Cu}>\mathrm{Zn}>\mathrm{Mn}>$ $\mathrm{Co}>\mathrm{Pb}>\mathrm{Cr}>\mathrm{Ni}>\mathrm{Cd}$. This is almost the same as the order of their correlation coefficients with $\mathrm{Fe}_{2} \mathrm{O}_{3}, \mathrm{Al}_{2} \mathrm{O}_{3}$ and $\mathrm{OM}$. These findings also validate a mechanism to predict
\end{abstract}

El-Sayed E. Omran

ee.omran@gmail.com

1 Soil and Water Department, Faculty of Agriculture, Suez Canal University, 41522 Ismailia, Egypt heavy metals that have no absorption features in reflectance spectra. The results concerning the relationships between spectral parameters and heavy metals concentration indicate that iron oxides, clay, and OM play an important role in the prediction of soil heavy metals using reflectance spectra. To identify the specific wavelengths for prediction of the studied heavy metals, the regression coefficient with $\mathrm{OM}, \mathrm{Al}_{2} \mathrm{O}_{3}$, and $\mathrm{Fe}_{2} \mathrm{O}_{3}$ were used. The most significant peaks for $\mathrm{Zn}$ prediction are found in the wavelengths of 430, 570, and $1700 \mathrm{~nm}$; for $\mathrm{Cu}$ prediction at 538, 1259, 1500, and $2184 \mathrm{~nm}$; for $\mathrm{Pb}$ significant peaks are at 440,578, 915, and $1894 \mathrm{~nm}$; for $\mathrm{Cr}$ at 860, 1001, and $2376 \mathrm{~nm}$; for Ni at 870, 909, and $2240 \mathrm{~nm}$; for Cd at 630, and $1270 \mathrm{~nm}$; for Co at 1900, and $2300 \mathrm{~nm}$. As the current results suggested, large concentrations of heavy metals can be predicted using reflectance spectroscopy. However, it is much more difficult to determine small concentrations of heavy metals in soils of Bahr El Baqar region. Organic matter masks spectral signatures, making it difficult to identify metal quantities at these wavelengths. So, a new concept "inference approach" in light of key soil constituents that absorb VNIR-SWIR radiation would became a powerful tool to enhance the accuracy of heavy metal prediction. Due to the interference effects of organic matter and low heavy metal concentration, the selection of the most sensitive original spectral bands still did not result in highly accurate prediction. Therefore, it is important to predict heavy metals through OM, iron oxides, or clays first. These results indicate that it is possible to predict heavy metals in soils using the rapid and economic reflectance spectroscopy.

Keywords Bahr El Baqar soil - Reflectance .

Spectroscopy - Partial least squares regression - Inference model $\cdot$ Heavy metals 


\section{Introduction}

The unreasonable utilization of natural (including land) resources by humans caused numerous ecological and environmental issues. Human and anthropogenic activities, such as excessive use of fertilizers, pesticides, sewage irrigation, and discharge of waste affected soil environment significantly. A standout amongst the most polluted drain by anthropogenic activities in Egypt is Bahr El-Baqar (Omran and Abd El Razek 2012). Saad (1997) concluded that $58 \%$ of the total drainage water of Bahr El-Baqar drain originate from agricultural drainage, $2 \%$ from industrial drainage and $40 \%$ from domestic and commercial drainage. Bahr El-Baqar drain conveys the greatest part of untreated wastewater into Lake Manzala through a very densely populated area passing through Qalubyia, Sharkia, Ismailia and Port Said Governorates. The soils of Bahr El-Baqar get numerous kinds of pollutants particularly heavy metals such as lead, cadmium, nickel, and mercury, which are considered the most hazardous (Park and Shin 2006). Soil heavy metals have been an exceptionally helpful indicator of environmental and soils quality, which affects the physico-chemical characteristics of soil ecosystems. Although conventional methods of soil heavy metals determination are sufficiently accurate, they are mostly based on wet digestion of soil samples in hot concentrated acids followed by atomic absorption spectrometry or inductively coupled plasma spectrometry. Therefore, these methods are time-consuming, expensive, and require environmentally damaging chemicals and qualified staff (Omran 2016). The cost for the expense for conventional soil characterization figured by the U.S. National Soil Survey Center, is about US $\$ 2500$ per pedon and requires 6-12 months to be accomplished (Brown et al. 2006; Rizzo et al. 2014). In this way, development of alternative environmentally friendly method that is accurate, rapid, and inexpensive is of great value.

Visible-near infrared-short wave infrared (VNIR-SWIR) reflectance spectroscopy is relatively less expensive and faster than traditional wet chemical measurements (Summers 2009). The VNIR-SWIR spectral wavelengths (e.g., 350-2500 nm) act as predictor variables, and the soil heavy metals are predicted by a statistical (e.g., partial least squares regression, PLSR) model. Two aspects can largely influence the VNIR-SWIR based determination of soil heavy metals. One is the spectra transformation/pre-processing technique, while the other is soil sample preparation (Stenberg et al. 2010). On one hand, some researchers have looked at the spectral curves of soil samples with various surface roughness and moisture conditions ( $\mathrm{Wu}$ et al. 2009). The investigation of such changes could be useful as the VNIR-SWIR spectra are known to carry comprehensive information of both chemical and physical phenomena. On the other hand, the spectral pre-processing technique has been considered an essential part of chemometrics modelling. To date, few studies, however, have assessed the data distribution of each wavelength after different spectral transformation, despite the important role that this plays in the correlation analysis between spectra and soil heavy metals. Moreover, its application permitted the baseline shift, light scattering and non-linearities to be largely removed (Rinnan et al. 2009). Unfortunately, VNIR region are dominated by powerless overtones and combination of vibration bands of atoms with strong molecular bonds containing nitrogen, oxygen and carbon attached to hydrogen and no absorption metals were found in this region. There vibrational modes are modulated by forming complexes with organic molecules containing $\mathrm{C}-\mathrm{H}, \mathrm{N}-\mathrm{H}$ and O-H bonds (Malley and Williams 1997).

Heavy metals as soil contaminants commonly occur in low concentrations $\left(10,000 \mathrm{mg} \mathrm{kg}^{-1}\right.$ dry soil). Inorganic material as a rule does not show characteristic absorption features in the VNIR-SWIR wavelength region (Wu et al. 2005; Schwartz et al. 2012; Pandit et al. 2010; Vohland et al. 2009; Zhang et al. 2010; Yaolin et al. 2011). It is therefore considered difficult to directly detect inorganic soil contaminants in general, and heavy metals in particular (Winkelmann 2005). Peng et al. (2013) inferred that the impact of organic matter $(\mathrm{OM})$ on quantitative estimation of the iron oxide content in soil is critical, especially when $\mathrm{OM}$ content exceeds $20 \mathrm{~g} \mathrm{~kg}^{-1}$. Therefore, the variation in OM content has a vital impact not only on the quantitative estimation of $\mathrm{OM}$ itself but also on that of other soil properties. When $\mathrm{OM}$ content exceeded $20 \mathrm{~g} \mathrm{~kg}^{-1}$, it is vital to adopt effective techniques to mitigate this effect (Peng et al. 2013).

So, a new concept "inference approach" in light of key soil constituents that absorb VNIR-SWIR radiation would became a powerful tool to enhance the accuracy of heavy metal prediction. While pure metals do not absorb in the VNIR-SWIR region, they might be detected indirectly through their complexing with OM, association with moieties such as hydroxides, sulfides, carbonates, or oxides, which are detectable, or adsorption to clays that absorb light in this wavelength range (Schwartz et al. 2012). Therefore, the objective of this study is to propose an inference model for heavy metals prediction $(\mathrm{Cd}, \mathrm{Cu}, \mathrm{Pb}$, $\mathrm{Zn}, \mathrm{Ni}, \mathrm{Mn}, \mathrm{Cr}, \mathrm{Fe}$ ) with VNIR-SWIR range in soil samples collected at Bahr El-Baqar region, Egypt. The present study is gear towards study the feasibility of different preprocessing VNIR-SWIR transformation for soil heavy metals inferences. The present study endeavors to answer two main questions: (1) is it possible to implement VNIRSWIR spectroscopy as alternative, fast and cost-effective 
method for soil heavy metals prediction under low concentrations? and (2) is it possible to establish successful calibration models for heavy metals inference with small number of samples collected at farm scale?

\section{Reflectance spectra of heavy metals}

Inorganic material such as heavy metals, which do not show characteristic absorption/reflection features, cannot be directly detected in the VNIR-SWIR region (Schwartz et al. 2012; Pandit et al. 2010; Zhang et al. 2010; Yaolin et al. 2011). Schwartz et al. (2012) proposed that soil contamination may be detected indirectly via association with moieties, which are detectable in the VNIR-SWIR region. Prediction of soil heavy metals from spectra, may be detected indirectly through primary correlations to well recognized absorptions (e.g. those for clay minerals, OM, or iron oxides) and those that rely on secondary correlations with the soil constituents that absorb VNIR-SWIR radiation (such as $\mathrm{pH}$, cation exchange capacity). Various spectroscopic techniques for evaluating heavy metals contamination have been identified (Wu et al. 2007; Choe et al. 2008; Minasny et al. 2009; Pandit et al. 2010). Table 1 summaries the previous results of soil heavy metals prediction via VNIR-SWIR spectroscopy.

In order to accurately predict soil contamination via a spectral signal, it is first necessary to understand the relationships between spectrally active constituents, which have direct and significant effect on the reflectance of heavy or trace metals (Wu et al. 2007; Minasny et al. 2009). OM, clay minerals, and iron oxides were principally responsible for predicting a range of heavy metals $(\mathrm{Cd}, \mathrm{Cu}$, $\mathrm{Fe}, \mathrm{Mn}, \mathrm{Ni}, \mathrm{Pb}$ and $\mathrm{Zn}$ ) based on multivariate regression. Zhang et al. (2010) has suggested that heavy metals such as $\mathrm{Pb}$ can be directly detected and can also be estimated indirectly using reflectance spectroscopy via correlations with iron oxide contents. Kemper and Sommer (2002) found a strong relationship between iron and heavy metals concentrations, including $\mathrm{Pb}$, when utilizing multiple linear regression analysis (MLR) and an artificial neural network. While Wu et al. (2007) found that Fe had a high correlation and high cross validation statistic with heavy metals, Vohland et al. (2009) found a strong correlation between $\mathrm{Pb}$ and other heavy metals and $\mathrm{Fe}$ and clay fractions. Yaolin et al. (2011) found good correlation between OM, $\mathrm{Pb}$ concentration and laboratory based data in the range of 564-624 nm. Moreover, there was a significant relationship between metal levels $(\mathrm{Cd}, \mathrm{Hg}, \mathrm{Pb})$ within the spectral domain 500-700 nm, which was related to OM (Bray et al. 2009; Ji et al. 2010; Pandit et al. 2010). Some authors reported good predictions of $\mathrm{Cd}, \mathrm{Co}$, and $\mathrm{Zn}(\mathrm{Wu}$ et al. 2007) while others reported poor predictions (Wu et al. 2007; Malley et al. 2004). Contradictory results have also been reported for $\mathrm{Cr}, \mathrm{Cu}, \mathrm{Ni}$ and $\mathrm{Pb}$ (Malley et al. 2004; $\mathrm{Wu}$ et al. 2007). Figure 1 shows the main characteristic spectral signatures and corresponding soil attributes and provides selected major spectral regions for some soil properties.

Table 1 Summary results of soil heavy metals prediction via VNIR-SWIR spectroscopy

\begin{tabular}{llll}
\hline Soil heavy metals predicted & Number of samples & Modeling method & Author \\
\hline $\mathrm{As}, \mathrm{Cd}, \mathrm{Cu}, \mathrm{Fe}, \mathrm{Hg}, \mathrm{Pb}, \mathrm{Zn}$ & 214 & MLR/ANN & Kemper and Sommer (2002) \\
$\mathrm{As}, \mathrm{Pb}$ & 346 & Polynomial fit & Kemper and Sommer (2003) \\
$\mathrm{Cd}, \mathrm{Cu}, \mathrm{Fe}, \mathrm{Ni}, \mathrm{Pb}, \mathrm{Zn}$ & 70 & PLSR & Siebielec et al. (2004) \\
$\mathrm{Hg}$ & 120 & PCR & Wu et al. (2005) \\
$\mathrm{As}, \mathrm{Cd}, \mathrm{Co}, \mathrm{Cr}, \mathrm{Cu}, \mathrm{Ni}, \mathrm{Pb}, \mathrm{Zn}$ & 61 & PLSR & Wu et al. (2007) \\
$\mathrm{As}, \mathrm{Pb}, \mathrm{Zn}$ & 49 & EMLR & Choe et al. (2008) \\
$\mathrm{As}, \mathrm{Cu}$ & 22 & EMLR & Choe et al. (2009) \\
$\mathrm{As}, \mathrm{Cu}, \mathrm{Fe}$ & 33 & PLSR & Ren et al. (2009) \\
$\mathrm{Cu}, \mathrm{Fe}, \mathrm{Mn}, \mathrm{Pb}, \mathrm{Zn}$ & 149 & PLSR & Vohland et al. (2009) \\
$\mathrm{As}, \mathrm{Cd}, \mathrm{Cr}, \mathrm{Cu}, \mathrm{Hg}, \mathrm{Pb}, \mathrm{Zn}$ & 122 & Linear regression & Ji et al. (2010) \\
$\mathrm{Cd}, \mathrm{Cu}, \mathrm{Mn}, \mathrm{Pb}, \mathrm{Zn}$ & 8 & PLSR & Pandit et al. (2010) \\
$\mathrm{Cd}, \mathrm{Cu}, \mathrm{Fe}, \mathrm{Mn}, \mathrm{Ni}, \mathrm{Pb}, \mathrm{Zn}, \mathrm{Cr}$ & PLSR & Gannouni et al. (2012) \\
$\mathrm{Zn}, \mathrm{Cu}, \mathrm{Pb}, \mathrm{Cr}, \mathrm{Ni}$ & 22 & PLSR & Todorova et al. (2014) \\
$\mathrm{Cu}, \mathrm{Mn}, \mathrm{Cd}, \mathrm{Zn}, \mathrm{Fe}, \mathrm{Pb}, \mathrm{As}$ & PLSR & Gholizadeh et al. (2015b) \\
$\mathrm{Ag}, \mathrm{Ba}, \mathrm{Be}, \mathrm{Cd}, \mathrm{Co}, \mathrm{Cr}, \mathrm{Cu}, \mathrm{Ni}, \mathrm{Pb}, \mathrm{Tl}, \mathrm{V}, \mathrm{Zn}$ & 229 & PLSR & Sakizadeh et al. (2015) \\
\hline
\end{tabular}

$M L R$ multiple linear regression analysis, EMLR extended multiple linear regression analysis, $A N N$ artificial neural networks, $P L S R$ partial least squares regression, $P C R$ principal component regression, $\mathrm{Pb}$ lead, $\mathrm{Zn}$ zinc, $\mathrm{Mn}$ manganese, $\mathrm{Fe}$ iron, $\mathrm{Cd}$ cadmium, $\mathrm{Cu}$ copper, $\mathrm{Cr}$ chrome, $\mathrm{Ni}$ nickel, As arsenic, $\mathrm{Hg}$ mercury, $\mathrm{Co}$ cobalt 


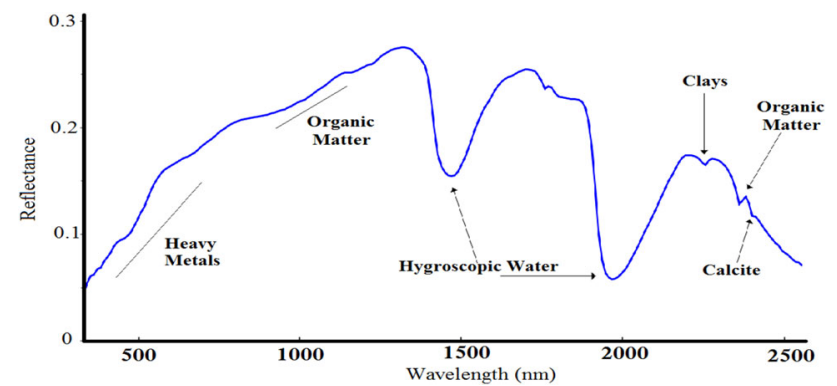

Fig. 1 Reflectance spectra of soil sample collected from Bahr ElBaqar region indicating the spectral features of the most important constitutes

\section{Materials and methods}

\section{Study area, soil sampling, and analysis}

Environmental and land resources in Bahr El-Baqar region are faced critical problems due to the increasing population, demolishing natural resources, heavy metals pollution, as well as others. A total of 35 soil samples was collected in 2014 from the study area which is located in northern Egypt, Bahr El-Baqar region, between $32^{\circ} 05^{\prime}$ to $32^{\circ} 16^{\prime}$ Longitude and $30^{\circ} 56^{\prime}$ to $31^{\circ} 07^{\prime}$ Latitude (Fig. 2). As few as 25 samples can result in good predictions at the farm or field scale (Wetterlind et al. 2008). One hundred to 200 samples might be at the lower limit for a model intended to cover a large geographical area with many and diverse soil types (Wetterlind et al. 2013). Outliers were examined and one samples were removed. 34 samples remained for soil heavy metals modeling and analysis. The samples were air-dried and crushed with a wooden pestle and mortar to pass through a $0.5 \mathrm{~mm}$ mesh-screen.

Nine metals are selected based on their: toxicity/environmental context, relation to local geology, irrigation activities, and data completeness and variability. The selected elements are lead $(\mathrm{Pb})$, zinc $(\mathrm{Zn})$, manganese $(\mathrm{Mn})$, iron $(\mathrm{Fe})$, cadmium $(\mathrm{Cd})$, copper $(\mathrm{Cu})$, chrome $(\mathrm{Cr})$, cobalt $(\mathrm{Co})$, and nickel $(\mathrm{Ni})$. The acidity $(\mathrm{pH})$ and soil salinity are also to be considered with the aforementioned parameters since they are important environmental indicators. Clay content and $\mathrm{OM}$ are selected as important parameter for indirectly prediction of heavy metals. Soil $\mathrm{pH}$ was measured in deionized water $\left(\mathrm{pH}_{\mathrm{w}}\right)$ and in $0.01 \mathrm{M}$ $\mathrm{CaCl}_{2}\left(\mathrm{pH}_{\mathrm{CaCl}}\right)$ (in 1:2.5 suspensions). Total organic carbon (TOC) was determined by wet digestion (Walkley and Black 1934).

\section{Overall methodology}

The overall methodology developed includes the following steps: (1) Set-up of a representative sample set from soil sampling strategy and chemical analysis. (2) Analysis of the samples following standard procedures. (3) Elaboration of a procedure for soil sample preparation before spectroscopic measurements. (4) Division of sample set into three groups: training, validation and test. The relationship between the soil heavy metals and the

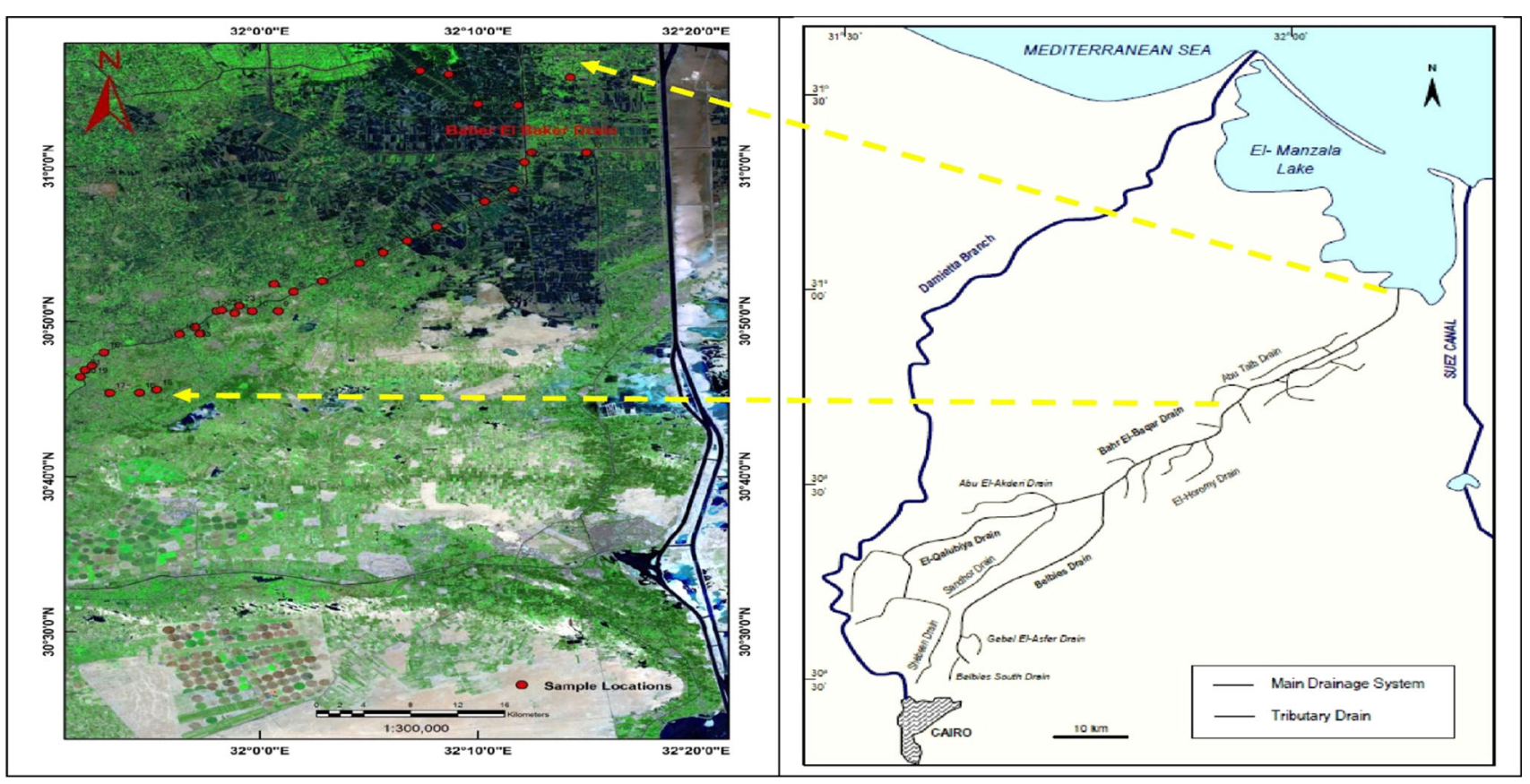

Fig. 2 Satellite image and sample locations for the study area (Omran 2016) 
Fig. 3 The overall methodology used to predict heavy metals of Bahr El Baqar soils using spectroscopy and chemometrics technique

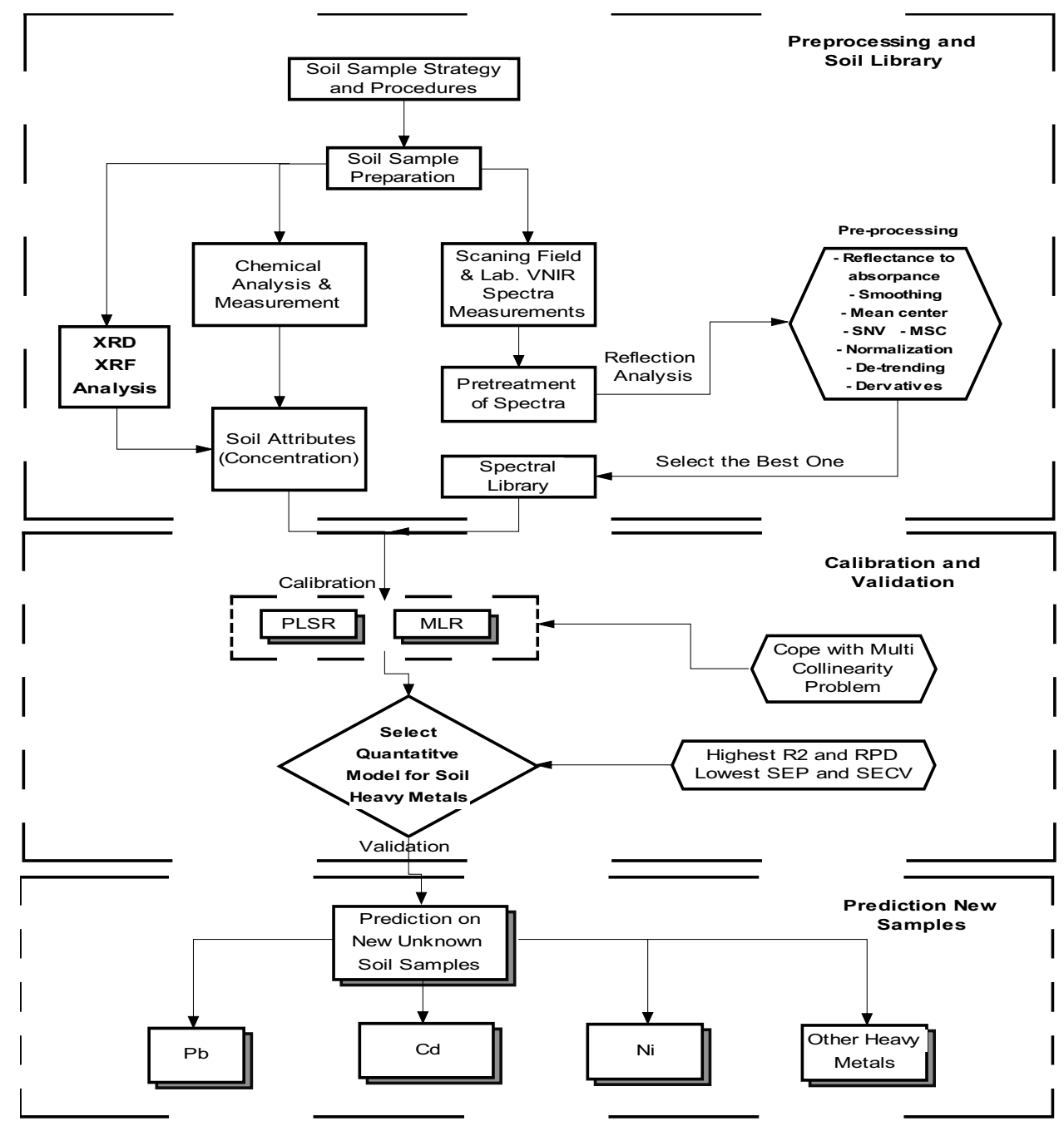

spectroscopy data is found via the training group and simultaneously cross-validated by the validation group. Finally, the model is applied to the test group, independent of the training and validation process. (5) Elaboration of a predictive model for each soil heavy metals (spectral data pre-treatment and calibration). (6) Evaluating the repeatability and reproducibility of the method. Figure 3 shows the overall methodology developed to achieve the study aim and build the most accurate models for predicting soil heavy metals.

The original soil reflectance spectra consisting of 2151 values (at $1 \mathrm{~nm}$ interval) between 350 and $2500 \mathrm{~nm}$ were averaged at every tenth nanometer wavelength. The new spectrum consisted of reflectance values at 350, 360, $370, \ldots 2500 \mathrm{~nm}$, inclusive. For example, the reflectance at $400 \mathrm{~nm}$ was an integrated reflectance values from 396 to $405 \mathrm{~nm}$. This procedure resulted in a new dataset with 214 wavelengths, that was approximately 1/10th the original data volume, while maintaining sufficient spectral information.

\section{Pre-processing and transformation methods}

Several pre-processing techniques were utilized to reduce the noise and to enhance the spectra or both. Scattercorrective methods and spectral derivatives are the most widely used pre-processing techniques in spectroscopy (Rinnan et al. 2009). Scatter-corrective methods incorporate multiplicative scatter correction (MSC), inverse MSC, extended MSC (EMSC), extended inverse MSC, detrending, standard normal variate (SNV) and normalization. Because of scatter modify for baseline shifts between samples, these techniques are intended to diminish the (physical) variability between samples. MSC is likely the most widely used pre-processing technique followed by SNV and derivation. Each spectrum is then corrected such that all samples seem to have the same scatter level as the reference spectrum (Vohland et al. 2009). Martens et al. (1983) was proposed to utilize just those parts of the spectral axis that do not include relevant information (baseline). It is difficult to decide such regions in practice, 
especially in near infrared (NIR) measurements, where the signals from different chemical components are strongly overlapping and correlated, and little or no true baseline is found. This is the motivation behind why, in most cases, the entire spectrum is utilized to locate the scalar correction parameters in MSC. SNV pre-processing is probably the second most applied method for scatter correction of the data (Barnes et al. 1989). MSC and SNV are the same for most practical applications.

The spectral derivation group is represented by NorrisWilliams (NW) derivative and Savitzky-Golay (SG) polynomial derivative. Derivatives have the ability to eliminate both additive and multiplicative effects in the spectra. Vasques et al. (2008) found that derivative procedure has the best transformations in pre-processing. Derivatives of the spectra may allow relevant information to be extracted from the near-infrared range (Ertlen et al. 2010). Both derivation techniques use smoothing in order not to reduce the signal-to-noise ratio in the corrected spectra too much. The parameters of the algorithm (interval width, polynomial order) ought to be carefully chosen to avoid amplification of spectral noise (Nicolaï et al. 2007). In order to find the derivative at centre point, a polynomial is fitted in a symmetric window on the raw data. When the parameters for this polynomial are calculated, the derivative of any order of this function can undoubtedly be discovered analytically, and this value is subsequently utilized as the derivative estimate for this center point. The number of points used to calculate the polynomial (window size) and the degree of the fitted polynomial are both decisions that should be made. Too small window (moving-window) will lead to the introduction of large artifacts in the corrected spectra and to a reduced signal-to-noise ratio. However, the larger the size of the window, the smaller the distinction between full and moving-window pre-processing.

Pre-processing methods, such as MSC, SNV, SavitzkyGolay, continuum removal (CR) and derivatives are mostly used in the multivariate calibration techniques to decide the best data (Gholizadeh et al. 2015a). The CR will minimize any brightness differences and emphasize the spectra's absorption bands. Spectroscopic measurements were performed in transmission mode, which can be quantified (to absorbance) using Beer's Law (Nicolaï et al. 2007). If the dataset does not follow Lambert-Beer's law (a linear relationship between the absorbance and the concentrations), additional factors in PLS regression can compensate for this non-ideal behavior of the spectral predictor (Martens and Næs 1989). The disadvantage of including such additional factors is an increase in model complexity and, in turn, most probably a reduction of the model robustness for future predictions. The utilization of combinations of pre-processing methods is abundant in literature (Rinnan et al. 2009).

\section{Soil heavy metals prediction}

The application of VNIR-SWIR spectroscopy for soil heavy metals prediction does not involve any (hazardous) chemicals. It is a non-destructive technique well suited for analyses of some of the essential constituents of the soil (Wetterlind et al. 2013). There are two approaches to predict heavy metals in soils: (1) supervised in which the chromophore absorption band in question is known and under saturation, and (2) unsupervised in which the chromophore absorption band is unknown and is affected by several factors. Whereas the first approach is valid for the infrared (IR) region by using selected wavebands and pre-treatment to prevent saturation, the second represents the case of reflectance spectroscopy across the VNIR-SWIR region. For that purpose, multivariate statistical techniques (chemometrics) are required to extract the information about the quality attributes that is hidden within the spectral information. Essentially, this involves regression techniques coupled with spectral pre-processing.

Pearson correlation coefficient was used to identify correlations between the selected heavy metals $(\mathrm{Cd}, \mathrm{Cr}$, $\mathrm{Cu}, \mathrm{Fe}, \mathrm{Mn}, \mathrm{Ni}, \mathrm{Zn}, \mathrm{Co}, \mathrm{Pb}$ ), iron oxides, clay and $\mathrm{OM}$. Multivariate analyses of the soil spectral data were performed using principal component analysis (PCA) and partial least squares regression (PLSR). PCA identifies patterns in spectral data, allowing the clustering of data and reducing the number of dimensions without the loss of information. PLSR is a technique used in chemometrics (e.g. Conforti et al. 2013) when there are many predictor variables, which are highly collinear. PLSR is based on latent variable decomposition of two sets of variables: the independent, $X$ (spectral reflectance bands) and the dependent variables, Y (heavy metals). The limited number of PLSR factors selected explains most of the variation in both predictors and responses. PLSR is thus a method where the information is commonly explained by the original $\mathrm{X}$ variables that is compressed into few variables known as PLS components (latent variables) (Conforti et al. 2013).

PLSR analysis was carried out using The Unscrambler v. 10.4 software (CAMO Software Inc., Woodbridge, NJ, USA). The soil analysis data determined by conventional analysis methods were added to the corresponding spectral files using the WinISI II (Ver. 1.04) software (FOSS NIRSystem/TECATOR, 1999). Matlab (version 8.1.347) and PLS-Toolbox 4.2 were used to fit PLSR calibration with leave-one-out cross-validations. The ENVI 5.3 software (Exelis Visual Information Solutions 2012) was used to perform the continuum removal. TSG software (http:// www.thespectralgeologist.com), was used for the visualization and also the quantification of this variability. 
Table 2 Summary descriptive statistics of representative physico-chemical properties of the Bahr El Baqar soils

\begin{tabular}{lcrrrrrrr}
\hline Properties & Minimum & Maximum & Range & Mean & Std. deviation & CV & Skewness & Kurtosis \\
\hline $\mathrm{Fe}$ & 7.80 & 87.96 & 80.16 & 47.45 & 25.19 & 634.38 & -0.04 & -1.31 \\
$\mathrm{Mn}$ & 13.73 & 98.73 & 85.00 & 58.98 & 23.39 & 547.26 & -0.32 & -0.81 \\
$\mathrm{Cu}$ & 7.73 & 280.30 & 272.58 & 65.70 & 54.68 & 2990.45 & 2.27 & 6.69 \\
$\mathrm{Zn}$ & 39.67 & 215.58 & 175.91 & 90.56 & 41.86 & 1752.64 & 0.76 & 0.76 \\
$\mathrm{Ni}$ & 61.32 & 88.73 & 27.41 & 73.22 & 7.96 & 63.34 & 0.74 & -0.41 \\
$\mathrm{~Pb}$ & 24.42 & 52.40 & 27.98 & 36.64 & 7.04 & 49.63 & 0.58 & 0.05 \\
$\mathrm{Cd}$ & 10.27 & 19.07 & 8.80 & 14.69 & 2.31 & 5.32 & 0.06 & -0.44 \\
$\mathrm{Co}$ & 70.51 & 113.82 & 43.31 & 89.72 & 12.58 & 158.29 & 0.66 & -0.71 \\
$\mathrm{Cr}$ & 84.92 & 134.06 & 49.14 & 106.96 & 12.26 & 150.23 & 0.16 & 0.07 \\
$\mathrm{OM}$ & 0.22 & 3.55 & 3.33 & 1.60 & 0.79 & 0.62 & 0.73 & 0.69 \\
$\mathrm{pH}$ & 7.58 & 8.82 & 1.24 & 8.00 & 0.30 & 0.09 & 0.81 & 0.25 \\
$\mathrm{Clay}$ & 3.24 & 80.00 & 76.76 & 26.61 & 24.52 & 601.14 & 1.01 & -0.51 \\
\hline
\end{tabular}

$\mathrm{CV}$ coefficient of variance\%, $\mathrm{Fe}, \mathrm{Mn}, \mathrm{Cu}, \mathrm{Zn}, \mathrm{Pb}, \mathrm{Cd}, \mathrm{Co}, \mathrm{Cr}$ are in $\mathrm{mg} \mathrm{kg}^{-1} ; \mathrm{OM}$ and clay are in\%

\section{Goodness-of-fit}

The following statistics was used to assess the prediction ability of calibration and validation models including, the coefficient of determination in calibration $\left(R^{2} \mathrm{c}\right)$ and validation $\left(R^{2} \mathrm{v}\right)$, the standard error of cross validation $\left(\mathrm{SE}_{\mathrm{CV}}\right)$ in calibration, the standard error of prediction $\left(\mathrm{SE}_{\mathrm{P}}\right)$ in validation. The satisfying the criteria for establishing the model where $R^{2}>0.70$ (Morón and Cozzolino 2003). The prediction capacity of the models was assed using the ratio performance deviation (RPD) parameter or standard deviation reference of validation (Conzález-Martín et al. 2007). The residual prediction deviation (RPD) in calibration (RPDc) and validation (RPDv) models (Pirie et al. 2005). The goodness-of-fit of the prediction inference model is determined by the $R^{2}$ and $\mathrm{RMSE}_{\mathrm{P}}$ values obtained from plotting observed concentrations vs the predicted concentrations for each variable. The RMSE $\mathrm{P}_{\mathrm{P}}$ value is the standard deviation of the predicted residuals error and is computed as the square root of (observed-predicted) ${ }^{2} / N$ (Umetrics 2002). According to Viscarra Rossel (2008), the RPD values were classified in the following way: RPDs between 1.5 and 2.0 indicate poor predictions; RPDs between 2.0 and 2.5 indicate good prediction and RPDs $>2.5$ very good/ excellent model prediction.

\section{Results and discussion}

\section{Heavy metal properties of the Bahr EI Baqar soils}

Errors related to the traditional chemical analysis to which the spectra are correlated will be included in the calibration model. Therefore, a statistical analysis of the soil data before using it for calibration is important. The mean, standard deviation, and range for each heavy metal are presented in Table 2. The $\mathrm{pH}$ average in Bahr El Baqar soils is about 8.00 , because of the presence of calcareous parent material. The relatively high content of soil organic matter (average 1.6\%) is mainly related to the high organic matter flux to soil due to direct discharge of domestic and industrial wastewaters. The dissolution of humic acid at high $\mathrm{pH}$ is responsible for dissolution of $\mathrm{Cu}$ and $\mathrm{Pb}$ from soil. Organic matter is important for the retention of metals by soil solids, thus decreasing mobility and bioavailability.

The summary statistics results indicate that the mean value of soil $\mathrm{Pb}, \mathrm{Cu}, \mathrm{Cr}$ and $\mathrm{Zn}$ concentrations is 36.64 , $65.70,106.96$, and $90.56 \mathrm{mg} \mathrm{kg}^{-1}$, respectively and the range between the minimum and maximum values is 27.98 , $272.58,49.14$, and $175.91 \mathrm{mg} \mathrm{kg}^{-1}$, respectively, which is large. There are great variations and high skewness for $\mathrm{Cu}$ and $\mathrm{Zn}(2.27$ and 0.76$)$. The CV\% values reflect the mean variation of each sampling site in the population. The order of the $\mathrm{CVs} \%$ for each element, from high to low, was $\mathrm{Cu}>\mathrm{Zn}>\mathrm{Fe}>\mathrm{Mn}>\mathrm{Co}>\mathrm{Cr}>\mathrm{Ni}>\mathrm{Pb}>\mathrm{Cd}$. This result showed that the variation of $\mathrm{Cu}$ and $\mathrm{Zn}$ in the soil was larger than other metals.

\section{Spectral signatures of Bahr El Baqar soils}

Figure 4(left) shows the spectra of all soil samples measured in laboratory, which show the typical soil reflectance shape in each region of wavelength domain. Reflectance is lower in the visible range $(350-650 \mathrm{~nm})$ and higher in the near infrared with specific absorbance bands around 1400 , 1900 and $2200 \mathrm{~nm}$. A promising relationship between the heavy metal concentrations and reflectance spectra was determined for the samples. Figure 4(right) shows the Bahr El Baqar soils with different heavy metals concentration. The spectral signatures of the soil samples changed significantly as a function of heavy metals concentration. It was hypothesized that the samples with the highest 

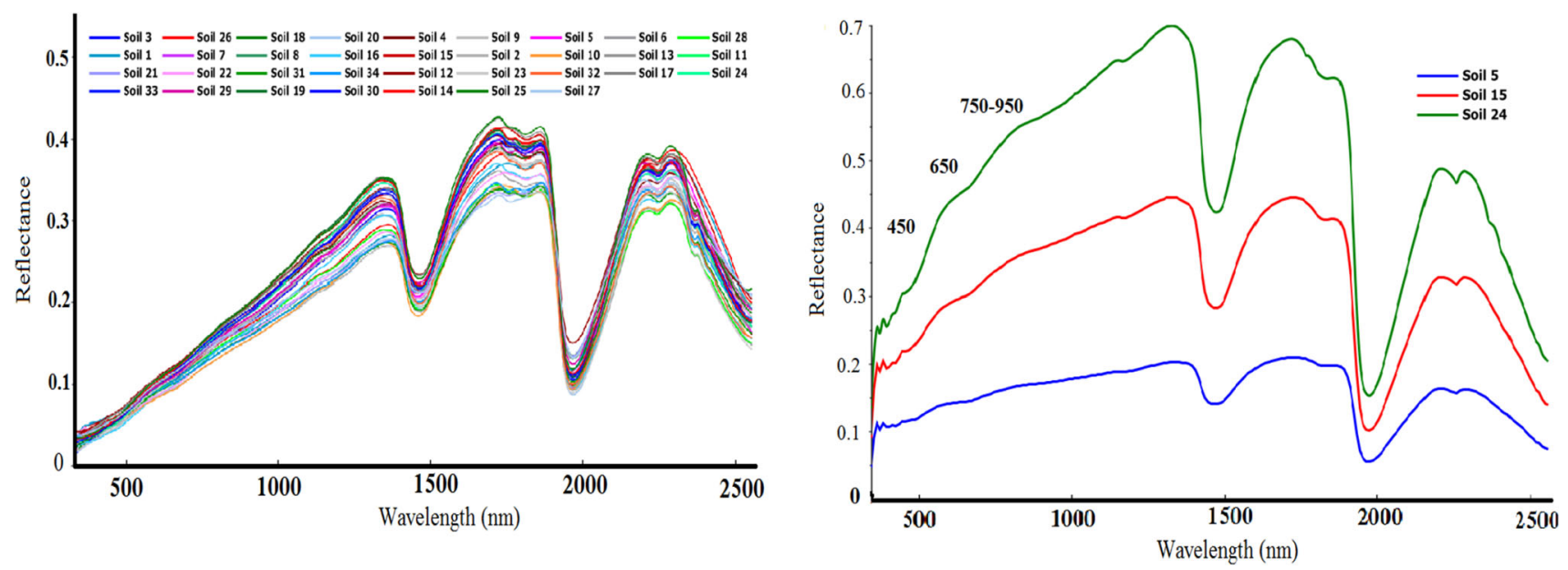

Fig. 4 Reflectance of soil samples (left) and a spectrum with wavelength position of different heavy metals concentration (right)

concentrations would have the lowest reflectance, and that the reflectance would increase proportionally as the heavy metal concentrations decreased.

To determine the relationship among soil parameters, Pearson correlation coefficients were calculated (Table 3). Table 3 shows the correlation coefficients of the heavy metals, clay, iron oxides, organic matter, and reflectance at 400, 800, 1200, and $1600 \mathrm{~nm}$ for the samples. The results revealed that the $\mathrm{Fe}$ is good correlated with $\mathrm{Mn}$ and moderately correlated with $\mathrm{Cu}$ and $\mathrm{Pb}(r=0.819,0.488$, 0.479 , respectively). Furthermore, there is a well correlation between $\mathrm{Ni}$ and $\mathrm{Co}(r=0.966)$. There are significant correlations between $\mathrm{Cu}$ and each of $\mathrm{Zn}, \mathrm{Pb},(r=0.678$, 0.544 , respectively) as shown in Table 3 . This result revealed that these metals have the same source of contamination. The $\mathrm{Ni}, \mathrm{Fe}, \mathrm{Mn}, \mathrm{Cu}, \mathrm{Zn}$ and $\mathrm{Co}$ are positively correlated with $\mathrm{OM}, \mathrm{pH}$ and clay. Clay highly correlated with $\mathrm{Fe}, \mathrm{Mn}, \mathrm{Cu}$, and $\mathrm{Zn}(0.773,0.658,0.786$, and 0.709, respectively). As can be seen in Table 3, there is a negative correlation between $\mathrm{pH}$ and each of $\mathrm{OM}$, clay, $\mathrm{Cu}$, and $\mathrm{Zn}$ since increasing the clay and OM leads to increasing the total acidity of these soils. By contrast, there is a positive correlation between $\mathrm{pH}$ and $\mathrm{Cu}$ and $\mathrm{Zn}$. A significant relationship is found between $\mathrm{Cd}, \mathrm{Cu}$ content and clay content. Considering all soil samples, $\mathrm{Pb}, \mathrm{Ni}$ and $\mathrm{Cr}$ content is not significantly related to clay content.

Overall, Table 3 shows that there is no direct correlations between heavy metals and reflection spectra at 400 , 800,1200 , and $1600 \mathrm{~nm}$. The linear relationship between heavy metal and reflectance is significant for 400 and $800 \mathrm{~nm}$. However, this relation is not significant for 1200 and $1600 \mathrm{~nm}$. Therefore, pre-processing spectra and selecting important wavelength from PLSR is important. Earlier research has shown that the calibration models, in which spectra are not pre-processed, are more sensitive to changes in environmental conditions compared to models for which pre-processing is applied (Moros et al. 2009). So one could still decide to use a pre-processing method to avoid this problem. Due to the numerous and high-correlated spectral data, band selection or band transformation is the prerequisite for heavy metal inference.

\section{Validation the important wavelengths and pre- processing for PLSR}

In this study, specific spectra measured in the laboratory were used for predicting metal concentration levels using different pre-processing methods (Table 4). The optimum calibration models were determined by the lowest standard error of calibration $\left(\mathrm{SE}_{\mathrm{CV}}\right)$ and standard error of prediction $\left(\mathrm{SE}_{\mathrm{P}}\right)$ and the highest correlation coefficient $\left(R^{2}\right)$. The ratio of standard error of performance to standard deviation (RPD) was used to evaluate the accuracy of prediction.

The use of PLSR for the prediction of the variables $\mathrm{Ni}$, $\mathrm{Cr}, \mathrm{Pb}, \mathrm{Zn}, \mathrm{Cu}, \mathrm{Cd}, \mathrm{Mn}$, and $\mathrm{Co}$ based on the specific spectral value leads to the results mentioned in the Table 4 . The pre-processing spectra of the samples were used to describe the chemical variables. All these chemical variables with exception of $\mathrm{Cu}, \mathrm{Cd}, \mathrm{Co}$ and $\mathrm{Fe}$ significantly have wavelengths for prediction in the following priority order: $\mathrm{Mn}>\mathrm{Pb}>\mathrm{Zn}>\mathrm{Cr}>\mathrm{Ni}$ according to the model quality (Table 4).

$\mathrm{Mn}, \mathrm{Zn}, \mathrm{Pb}, \mathrm{Cu}$, and $\mathrm{Ni}$, had significant coefficients of determination $0.62,0.66,0.66,0.60,0.69$, respectively for the validation samples, indicating that the partial leastsquares calibration model has low predictive power to estimate metal abundance. Based on Table 2, $\mathrm{Cu}$ and $\mathrm{Zn}$ have larger variation $(\mathrm{CV})$ than other heavy metals. $\mathrm{Co}, \mathrm{Cr}$, and $\mathrm{Cd}$ had low coefficients of determination $(0.55,0.52$, 0.59 , respectively) for the validation samples. Based on Table 4, specific spectral pre-processing increases the accuracy of all heavy metals. The application of most of 


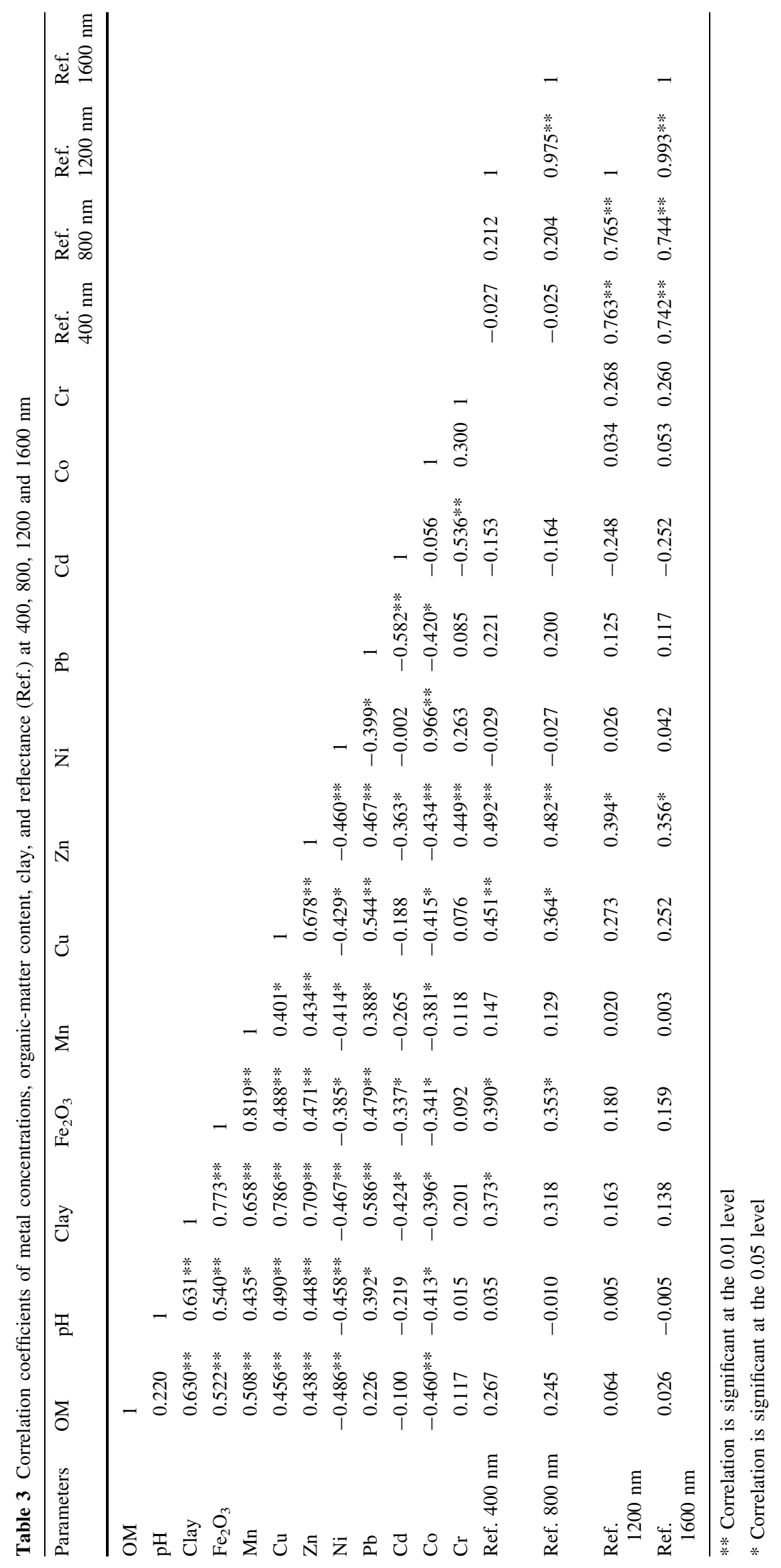


Table 4 Validation the most important and significant spectra range $(\mathrm{nm})$ for heavy metals prediction

\begin{tabular}{|c|c|c|c|c|c|c|c|}
\hline Heavy metals & Original spectra range, $\mathrm{nm}$ & Treatment & $R^{2}$ & $\mathrm{RMSE}_{\mathrm{CV}}$ & $\mathrm{SE}_{\mathrm{P}}$ & $\mathrm{SE}_{\mathrm{CV}}$ & RPD \\
\hline \multirow[t]{3}{*}{$\mathrm{Mn}$} & \multirow[t]{3}{*}{$390-550$} & 1 st & 0.58 & 16.50 & 26.50 & 23.27 & 1.42 \\
\hline & & 2nd & 0.62 & 10.50 & 26.09 & 21.45 & 2.23 \\
\hline & & $\mathrm{CR}$ & 0.35 & 20.12 & 27.24 & 25.21 & 1.16 \\
\hline \multirow[t]{3}{*}{$\mathrm{Cu}$} & \multirow[t]{3}{*}{$1259,1422,1629$} & 1 st & 0.43 & 42.40 & 57.87 & 54.99 & 1.29 \\
\hline & & 2nd & 0.46 & 51.52 & 53.18 & 50.64 & 1.06 \\
\hline & & $\mathrm{CR}$ & 0.60 & 25.45 & 49.41 & 48.24 & 2.15 \\
\hline \multirow[t]{3}{*}{$\mathrm{Zn}$} & \multirow[t]{3}{*}{$430-570,1151-1164,1421,1618,1721$} & 1 st & 0.65 & 38.32 & 45.29 & 41.63 & 1.09 \\
\hline & & 2nd & 0.66 & 20.42 & 44.91 & 41.49 & 2.05 \\
\hline & & $\mathrm{CR}$ & 0.42 & 39.11 & 46.32 & 43.25 & 1.07 \\
\hline \multirow[t]{3}{*}{$\mathrm{Ni}$} & \multirow[t]{3}{*}{$870-990,909,1411-1436$} & 1 st & 0.42 & 7.69 & 8.34 & 8.02 & 1.04 \\
\hline & & 2nd & 0.46 & 6.80 & 8.74 & 7.01 & 1.17 \\
\hline & & $\mathrm{CR}$ & 0.69 & 3.72 & 8.10 & 6.90 & 2.15 \\
\hline \multirow[t]{3}{*}{$\mathrm{Pb}$} & \multirow{3}{*}{$\begin{array}{l}440-584,915,1065,1151-1168,1430 \\
\quad 1632\end{array}$} & 1 st & 0.66 & 3.50 & 7.90 & 6.67 & 2.01 \\
\hline & & 2nd & 0.62 & 6.12 & 8.02 & 6.85 & 1.15 \\
\hline & & $\mathrm{CR}$ & 0.32 & 6.91 & 8.15 & 7.52 & 1.02 \\
\hline \multirow[t]{3}{*}{$\mathrm{Cd}$} & \multirow[t]{3}{*}{$907,1270,1430,1528$} & 1 st & 0.41 & 1.85 & 2.47 & 2.34 & 1.25 \\
\hline & & 2nd & 0.52 & 1.12 & 2.43 & 2.31 & 2.10 \\
\hline & & $\mathrm{CR}$ & 0.33 & 1.45 & 2.91 & 2.95 & 1.59 \\
\hline \multirow[t]{3}{*}{ Co } & \multirow[t]{3}{*}{$238,400-780$} & 1 st & 0.39 & 10.52 & 13.15 & 12.77 & 1.20 \\
\hline & & 2nd & 0.35 & 12.36 & 11.58 & 10.58 & 1.02 \\
\hline & & $\mathrm{CR}$ & 0.55 & 6.20 & 10.82 & 10.01 & 2.03 \\
\hline \multirow[t]{3}{*}{$\mathrm{Cr}$} & \multirow[t]{3}{*}{ 860-1001 } & 1 st & 0.52 & 11.23 & 13.34 & 12.21 & 1.09 \\
\hline & & $2 n d$ & 0.59 & 6.11 & 12.37 & 11.83 & 2.01 \\
\hline & & $\mathrm{CR}$ & 0.21 & 11.25 & 13.65 & 12.20 & 1.09 \\
\hline
\end{tabular}

$1 s t$ first derivative, $2 n d$ second derivative, $C R$ continuum removal

the pre-processing methods for these heavy metals increased the accuracy of prediction, which was similar to the conclusion drawn by Ren et al. (2009).

Figure 5 shows validation results of the heavy metals concentration using different pre-processing methods on the spectra. According to the criteria of minimal RMSEcv and maximal $R^{2} \mathrm{cv}$, the second derivatives method was considered as the foremost techniques for predicting $\mathrm{Mn}$, $\mathrm{Zn}, \mathrm{Cd}$, and $\mathrm{Cr}$, respectively. However, the $\mathrm{CR}$ pre-processing method was chosen as the best algorithm for $\mathrm{Cu}$, $\mathrm{Ni}$, and Co. The first derivatives method was considered as the foremost techniques for predicting $\mathrm{Pb}$ only. Although the prediction ability with the different pre-processing of specific spectra was improved, it is still under the satisfying threshold.

\section{Heavy metals inference using $\mathrm{OM}, \mathrm{Al}_{2} \mathrm{O}_{3}$, and $\mathrm{Fe}_{2} \mathrm{O}_{3}$}

Due to the interference effects of organic matter and low heavy metal concentrations for all soil samples (Table 2), the selection of the most sensitive original spectral bands did not result in highly accurate prediction (Table 4;
Fig. 5). Organic matter masks spectral signatures, making it difficult to identify metal quantities at these wavelengths (Fig. 6). Therefore, it is important to predict heavy metals through $\mathrm{OM}$, iron oxides $\left(\mathrm{Fe}_{2} \mathrm{O}_{3}\right)$, or clays first. Figure 6 shows the heavy metals inference using $\mathrm{OM}, \mathrm{Al}_{2} \mathrm{O}_{3}$, and $\mathrm{Fe}_{2} \mathrm{O}_{3}$.

To identify the specific wavelengths for prediction of the studied heavy metals, the regression coefficient (Table 5) with $\mathrm{OM}, \mathrm{Al}_{2} \mathrm{O}_{3}$, and $\mathrm{Fe}_{2} \mathrm{O}_{3}$ were used. The most significant peaks for $\mathrm{Zn}$ prediction are found in the wavelengths of 430, 570, and $1700 \mathrm{~nm}$; for $\mathrm{Cu}$ prediction at 538, 1259, 1500 , and $2184 \mathrm{~nm}$; for $\mathrm{Pb}$ significant peaks are at 440 , 578, 915, and $1894 \mathrm{~nm}$; for $\mathrm{Cr}$ at 860, 1001, and $2376 \mathrm{~nm}$; for $\mathrm{Ni}$ at 870,909 , and $2240 \mathrm{~nm}$; for $\mathrm{Cd}$ at 630 and $1270 \mathrm{~nm}$; for Co at 1900 and $2300 \mathrm{~nm}$.

Absorptions at $1500 \mathrm{~nm}$ are connected with amine $\mathrm{N}-\mathrm{H}$ vibrations in organic components (Tekin et al. 2012). Absorptions at $1900 \mathrm{~nm}$ are connected with absorption of $\mathrm{H}-\mathrm{O}-\mathrm{H}$ bending and $\mathrm{O}-\mathrm{H}$ stretching vibrations in montmorilonite (Viscarra Rossel et al. 2006). Absorptions at $2170 \mathrm{~nm}$ are connected with $\mathrm{Al}-(\mathrm{OH})$ bands in albite and at $2240 \mathrm{~nm}$ with $\mathrm{Fe}-(\mathrm{OH})$ bands in iron minerals (Gaydon 

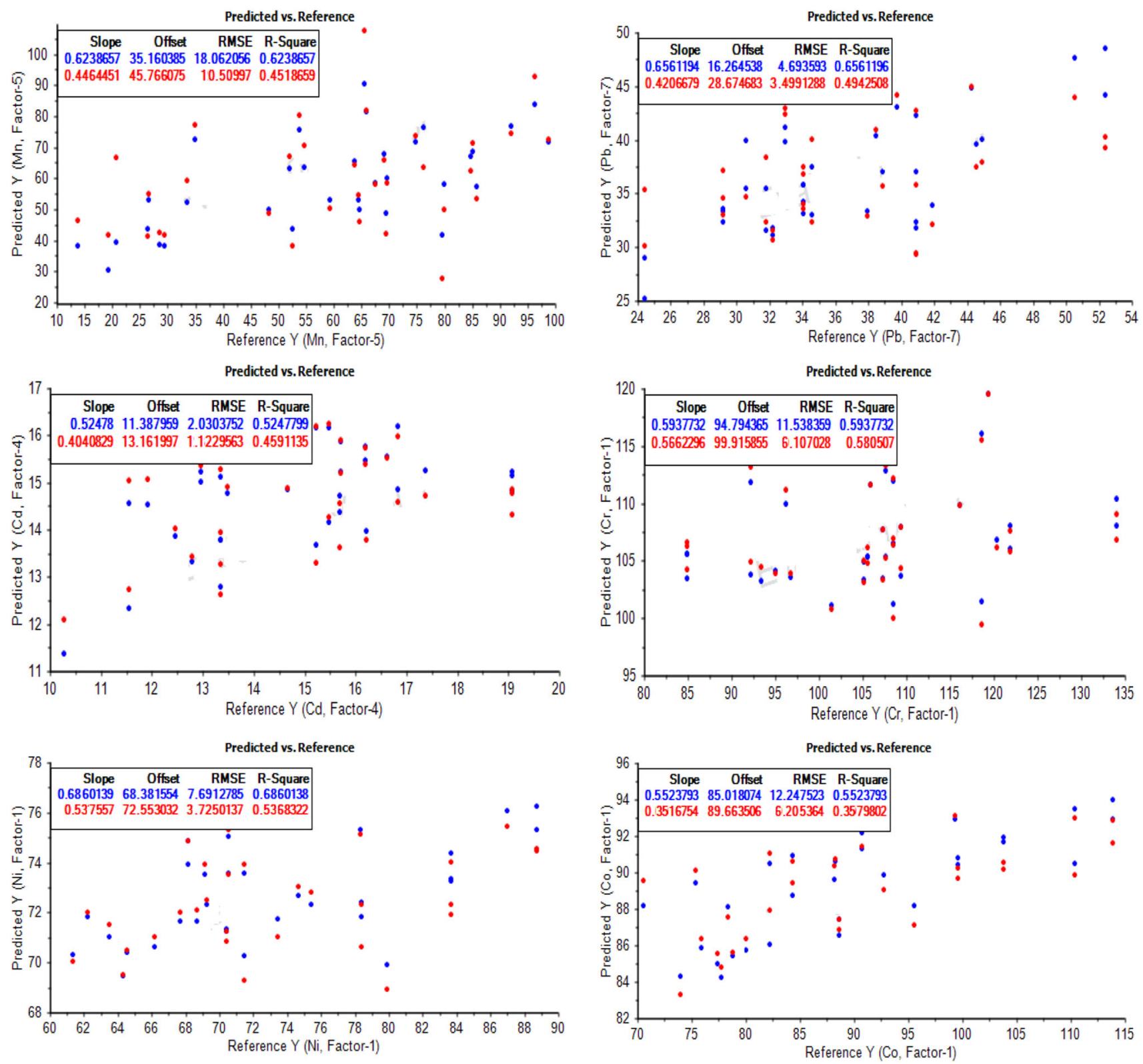

Fig. 5 Validation and prediction results of the pre-processing models for the heavy metals concentration (in $\mathrm{mg} / \mathrm{kg}$ )

et al. 2009). The absorption near $2300 \mathrm{~nm}$ is connected with $\mathrm{Mg}-\mathrm{OH}$ bending and $\mathrm{O}-\mathrm{H}$ stretching vibrations in soil minerals, like chlorite, illite and vermiculite (Viscarra Rossel et al. 2006). These significant wavebands support the assumption that measurements of heavy metals with VNIR-SWIR are performed by co-variation with water, clay, organic carbon and some minerals in the soil (Wu et al. 2007).

The heavy metals have different correlation coefficients with spectra, but the strongest correlated bands differ and are indicative of their binding information. The heavy metals display different correlation features (Tables 5, 6) and can be divided into three groups. Group I has $\mathrm{Cr}$, which is related to iron oxides, clays, and organic matter. $\mathrm{Cr}$ shows high spectral correlations at the $2376 \mathrm{~nm}$ spectral bands related to $\mathrm{Fe}(\mathrm{Mg}, \mathrm{Al})-\mathrm{OH}$ from iron oxides and clays, and $\mathrm{C}-\mathrm{H}$ absorption from organic matter, reflecting its binding feature to all these fine soil constitutes. Group II has $\mathrm{Ni}$ and $\mathrm{Mn}$, which is related to iron oxides and clays. Ni and Mn show high spectral correlations at the 870 and $2240 \mathrm{~nm}$ spectral bands, respectively. Group III has $\mathrm{Cu}$, which is related to iron oxides. $\mathrm{Cu}$ has strong correlations with bands resulting from $\mathrm{Fe}^{3+}$ absorption at $538 \mathrm{~nm}$. This suggest that binding to iron oxides is the most important form of $\mathrm{Cu}$. Group V has $\mathrm{Co}$, which is related to clays. Co shows high spectral correlations at the $1900 \mathrm{~nm}$ spectral 


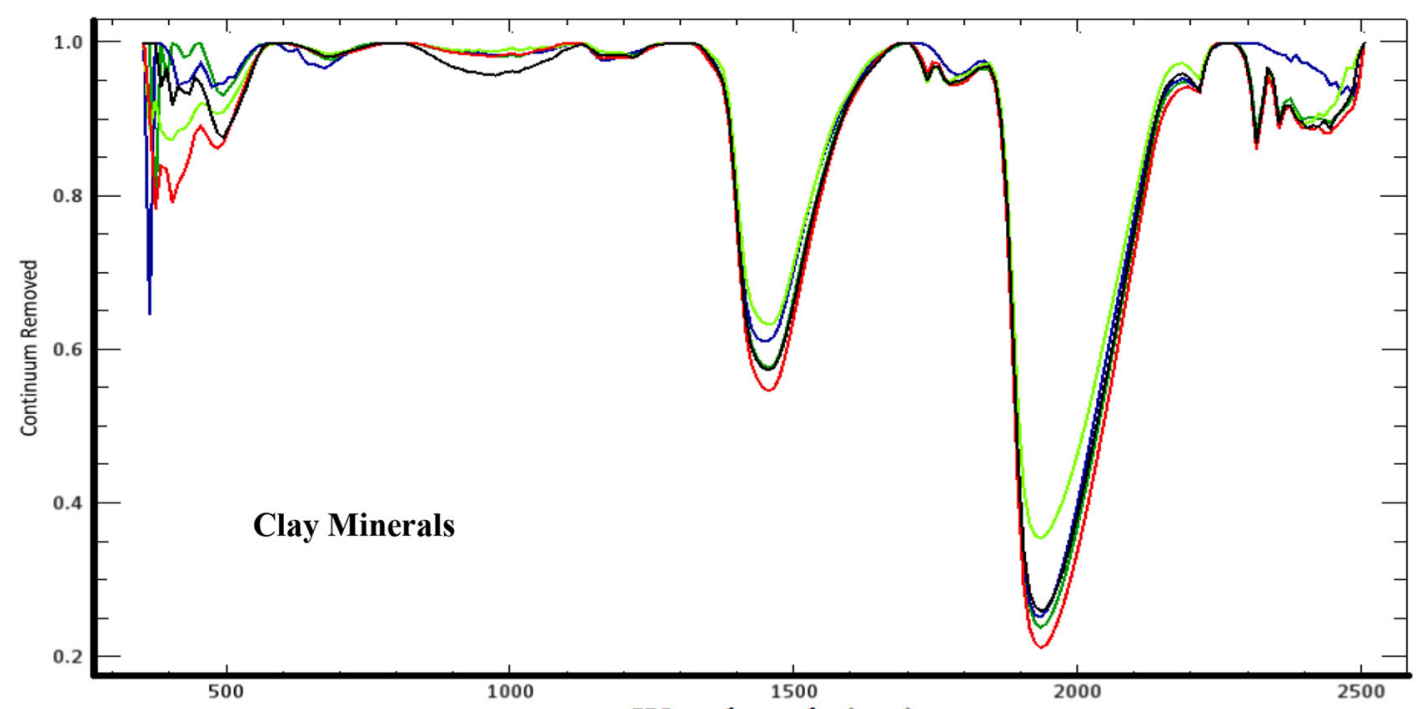

Wavelength (nm)
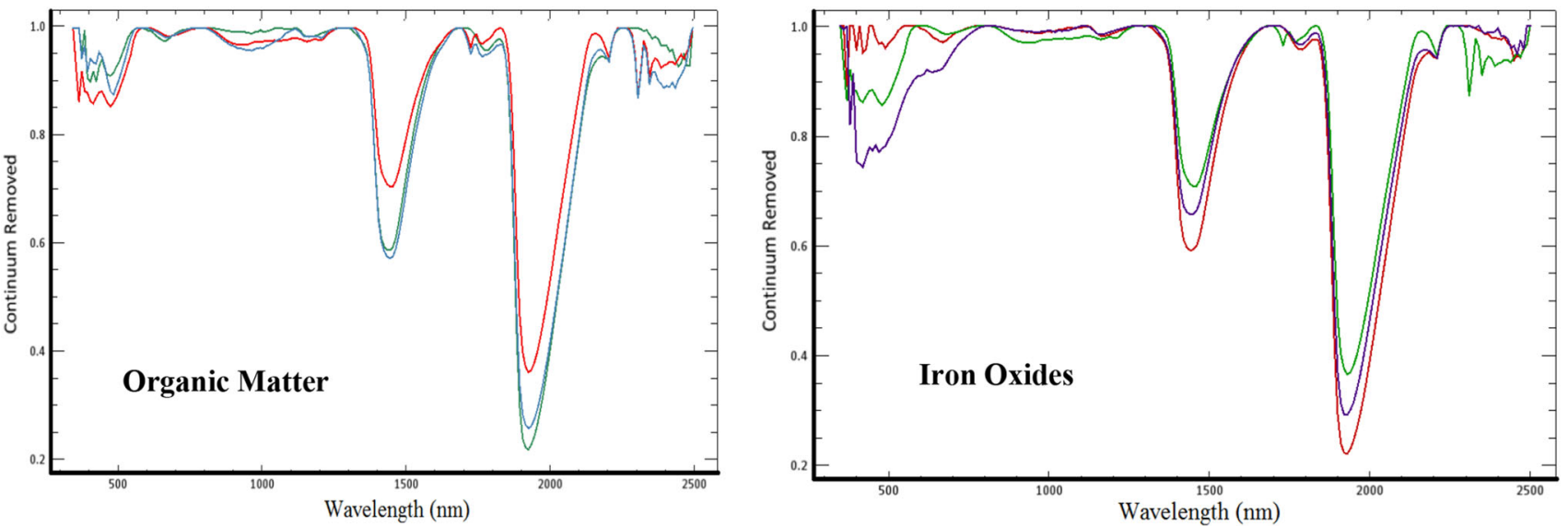

Fig. 6 Continuum removal of spectra for heavy metals inference using organic matter (OM), $\mathrm{Al}_{2} \mathrm{O}_{3}$, and $\mathrm{Fe}_{2} \mathrm{O}_{3}$

bands. Group IV has $\mathrm{Cd}$ and $\mathrm{Pb}$, which is related to organic matter. $\mathrm{Cd}$ and $\mathrm{Pb}$ only exhibit good correlation with reflectance (630 and 578, respectively) of the spectral regions between 500 and $700 \mathrm{~nm}$, which are strongly related to the total carbon contents of the soils, suggesting that $\mathrm{Cd}$ and $\mathrm{Pb}$ are only strongly associated with organic matters, not with iron oxides or clays. Zn displays high correlations with spectral regions at around $1700 \mathrm{~nm}$, which is related to the first overtone of $\mathrm{C}-\mathrm{H}$ stretch from organic matter; thus binding with organic matter is the dominant form of $\mathrm{Zn}$.

For example: The $\mathrm{Pb}$ concentration can be predicted as in the following equations.

$\mathrm{Pb}(\mathrm{ppm})=0.0775 \mathrm{OM}+35.286$

$\mathrm{OM}(\%)=1.344+0.0197 \mathrm{TS}_{\mathrm{crDOA} 600}$

$\mathrm{Pb}(\mathrm{ppm})=0.0775 \times 1.344+0.0197 \mathrm{TS}_{\mathrm{crDOA} 600}+35.286$
Therefore, the proposed "inference model" approach in light of key soil constituents that absorb VNIR-SWIR radiation would became a powerful tool to enhance the accuracy of heavy metal prediction. While pure metals do not absorb in the VNIR-SWIR region, they might be detected indirectly through their complexing with organic matter (OM), association with moieties such as iron oxides, which are detectable, or adsorption to clays that absorb light in this wavelength range (Table 6).

\section{Validation some selected ( $\mathrm{Cd}$, Fe and $\mathrm{Pb}$ ) heavy metals using XRD and SEM}

The morphology and composition of the soil samples were examined by scanning electron microscopy (SEM) and $\mathrm{X}$-ray diffraction (XRD). The samples can be divided into two groups, those with small (OM $\leq 3 \%$ e.g., soils 12,22 , $25)$ and those with large (OM $>3 \%$ e.g., soils 5, 9, 15) TOC 
Table 5 The regression coefficients obtained with partial least squares regression analysis between heavy metals and $\mathrm{Fe}_{2} \mathrm{O}_{3}, \mathrm{Al}_{2} \mathrm{O}_{3}$, and $\mathrm{OM}$

\begin{tabular}{|c|c|c|c|c|c|c|}
\hline \multirow[t]{2}{*}{ Heavy metals } & \multirow[t]{2}{*}{ Wavelength, nm } & \multicolumn{3}{|c|}{ Correlation coefficient } & \multirow[t]{2}{*}{ Prediction equation of heavy metals, ppm } & \multirow[t]{2}{*}{$R^{2}$} \\
\hline & & $\mathrm{Fe}_{2} \mathrm{O}_{3}$ & $\mathrm{Al}_{2} \mathrm{O}_{3}$ & $\mathrm{OM}$ & & \\
\hline \multirow[t]{3}{*}{$\mathrm{Mn}$} & 390 & $0.357 *$ & $0.352^{*}$ & 0.191 & & \\
\hline & 550 & $0.407 *$ & $0.400^{*}$ & 0.247 & & \\
\hline & 2240 & $0.465^{*}$ & $0.425^{*}$ & 0.251 & $\mathrm{Mn}=56.456 \mathrm{e}^{-0.004 \mathrm{x}}$ & 0.59 \\
\hline \multirow[t]{3}{*}{$\mathrm{Cu}$} & 538 & $0.603 *$ & $0.496^{*}$ & 0.238 & & \\
\hline & 1259 & $0.355^{*}$ & 0.321 & 0.246 & & \\
\hline & 2184 & $0.652 *$ & 0.422 & 0.266 & $\mathrm{Cu}=0.2376 \mathrm{x}^{2}-9.3202 \mathrm{x}+53.16$ & 0.64 \\
\hline \multirow[t]{3}{*}{$\mathrm{Zn}$} & 430 & $0.370 *$ & $0.366^{*}$ & 0.199 & & \\
\hline & 570 & 0.274 & 0.207 & 0.262 & & \\
\hline & 1700 & $0.351 *$ & 0.325 & $0.412 *$ & $\mathrm{Zn}=84.346 \mathrm{x}^{-0.015}$ & 0.69 \\
\hline \multirow[t]{3}{*}{$\mathrm{Ni}$} & 870 & $0.581 *$ & $0.558^{*}$ & 0.259 & $\mathrm{Ni}=73.088 \mathrm{e}^{-2 \mathrm{E}-04 \mathrm{x}}$ & 0.65 \\
\hline & 909 & $0.374 *$ & $0.348^{*}$ & 0.253 & & \\
\hline & 2240 & $0.421 *$ & $0.452^{*}$ & 0.243 & & \\
\hline \multirow[t]{4}{*}{$\mathrm{Pb}$} & 440 & $0.374 *$ & $0.371^{*}$ & 0.203 & & \\
\hline & 578 & 0.268 & 0.310 & $0.613 *$ & $\mathrm{~Pb}=0.0124 \mathrm{x}^{2}-0.3577 \mathrm{x}+37.897$ & 0.68 \\
\hline & 915 & $0.373 *$ & $0.347 *$ & 0.253 & & \\
\hline & 1894 & $0.352 *$ & 0.322 & 0.266 & & \\
\hline \multirow[t]{2}{*}{$\mathrm{Cd}$} & 630 & 0.382 & 0.211 & $0.517 *$ & $\mathrm{Cd}=-0.026 \ln (\mathrm{x})+14.757$ & 0.49 \\
\hline & 1270 & $0.354 *$ & 0.320 & 0.246 & & \\
\hline \multirow[t]{2}{*}{ Co } & 1900 & 0.214 & $0.654^{*}$ & 0.243 & $\mathrm{Co}=86.097 \mathrm{x}^{0.0122}$ & 0.56 \\
\hline & 2300 & 0.353 & $0.634^{*}$ & 0.323 & & \\
\hline \multirow[t]{3}{*}{$\mathrm{Cr}$} & 860 & $0.383^{*}$ & $0.361^{*}$ & $0.374 *$ & & \\
\hline & 1001 & $0.369 *$ & $0.340^{*}$ & 0.240 & & \\
\hline & 2376 & $0.632 *$ & $0.691^{*}$ & $0.587 *$ & $\mathrm{Cr}=109.42 \mathrm{e}^{-0.002 \mathrm{x}}$ & 0.67 \\
\hline
\end{tabular}

$\mathrm{X}=$ wavelength, $\mathrm{nm}$

* Correlation is significant at the 0.05 level

Table 6 The prediction equations obtained with regression analysis between the specific wavelengths and heavy metals utilized $\mathrm{Fe}_{2} \mathrm{O}_{3}, \mathrm{Al}_{2} \mathrm{O}_{3}$, and $\mathrm{OM}$ equations

\begin{tabular}{|c|c|c|c|c|}
\hline Group & $\begin{array}{l}\text { Heavy } \\
\text { metals }\end{array}$ & Prediction through & $\begin{array}{l}\text { Prediction equations of heavy } \\
\text { metals, ppm }\end{array}$ & $R^{2}$ \\
\hline 1 & $\mathrm{Cr}$ & Iron oxides, clays, or organic matter & $\mathrm{Cr}=-0.1775$ Iron oxides +110.07 & 0.67 \\
\hline \multirow[t]{2}{*}{2} & $\mathrm{Ni}$ & Iron oxides or clays & $\mathrm{Ni}=-0.0197$ Iron oxides +73.56 & 0.71 \\
\hline & Mn & & $\mathrm{Mn}=-0.065$ Iron oxides +60.117 & 0.66 \\
\hline 3 & $\mathrm{Cu}$ & $\begin{array}{l}* \text { Iron oxides }\left(\mathrm{mg} \mathrm{kg}^{-1}\right)=5.07+66.67 \mathrm{TS}_{1 \mathrm{D} 425}^{\mathrm{st}}+77.32 \\
\mathrm{TS}_{1 \mathrm{D} 1025}^{\mathrm{st}}-79.38 \mathrm{TS}_{1 \mathrm{D} 1075}^{\mathrm{st}}\left(R^{2}=0.68\right)\end{array}$ & $\mathrm{Cu}=-1.0036$ Iron oxides +83.264 & 0.68 \\
\hline 4 & Co & $*$ Clay $(\%)=28.15+\left(-0.092 \mathrm{TS}_{\mathrm{cr} 2200}\right)\left(R^{2}=0.57\right)$ & $\mathrm{Co}=-0.0162$ Clay +90.002 & 0.72 \\
\hline \multirow[t]{3}{*}{5} & $\mathrm{Cd}$ & $* \mathrm{OM}(\%)=1.344+0.0197 \mathrm{TS}_{\mathrm{CrDOA} 600}\left(R^{2}=0.53\right)$ & $\mathrm{Cd}=0.0003 \mathrm{OM}+14.685$ & 0.70 \\
\hline & $\mathrm{Pb}$ & & $\mathrm{Pb}=0.0775 \mathrm{OM}+35.286$ & 0.67 \\
\hline & $\mathrm{Zn}$ & & $\mathrm{Zn}=-0.1735 \mathrm{OM}+93.598$ & 0.73 \\
\hline
\end{tabular}

* Adopted from Omran 2017 (personal communication)

TS $_{2200}$ Transformed spectra peak at $2200 \mathrm{~nm}$

TS1 1 t $_{D 425}$ Transformed spectra using first derivative at $425 \mathrm{~nm}$

$T S_{\text {CrDOA600 }}$ The deviation of the arch of the continuum removal spectra at $600 \mathrm{~nm}$ 

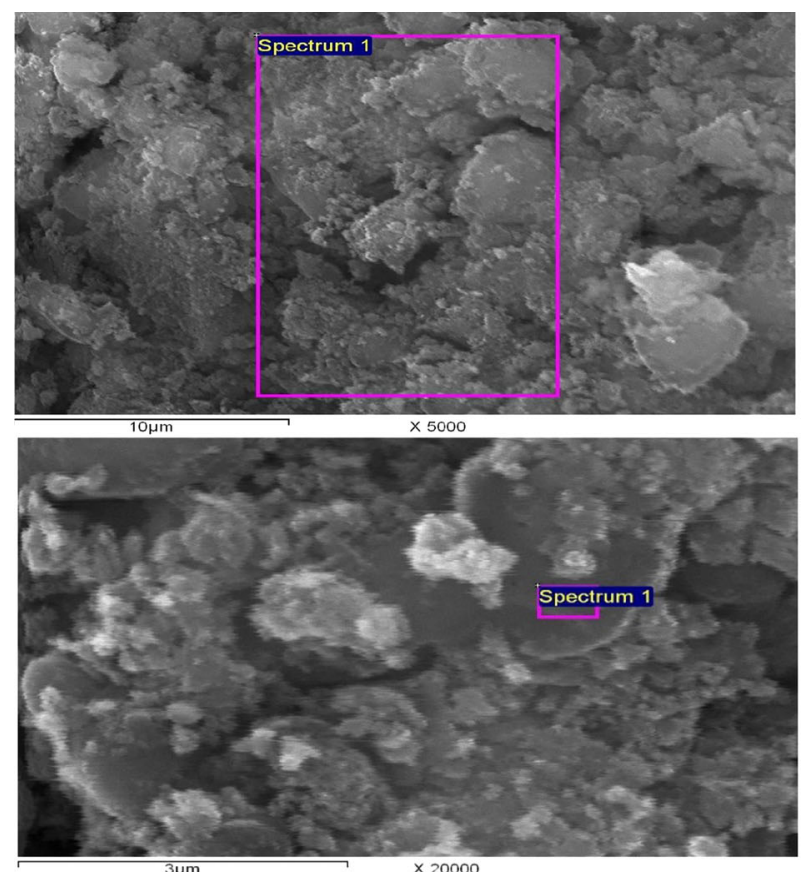

$3 \mu \mathrm{m}$
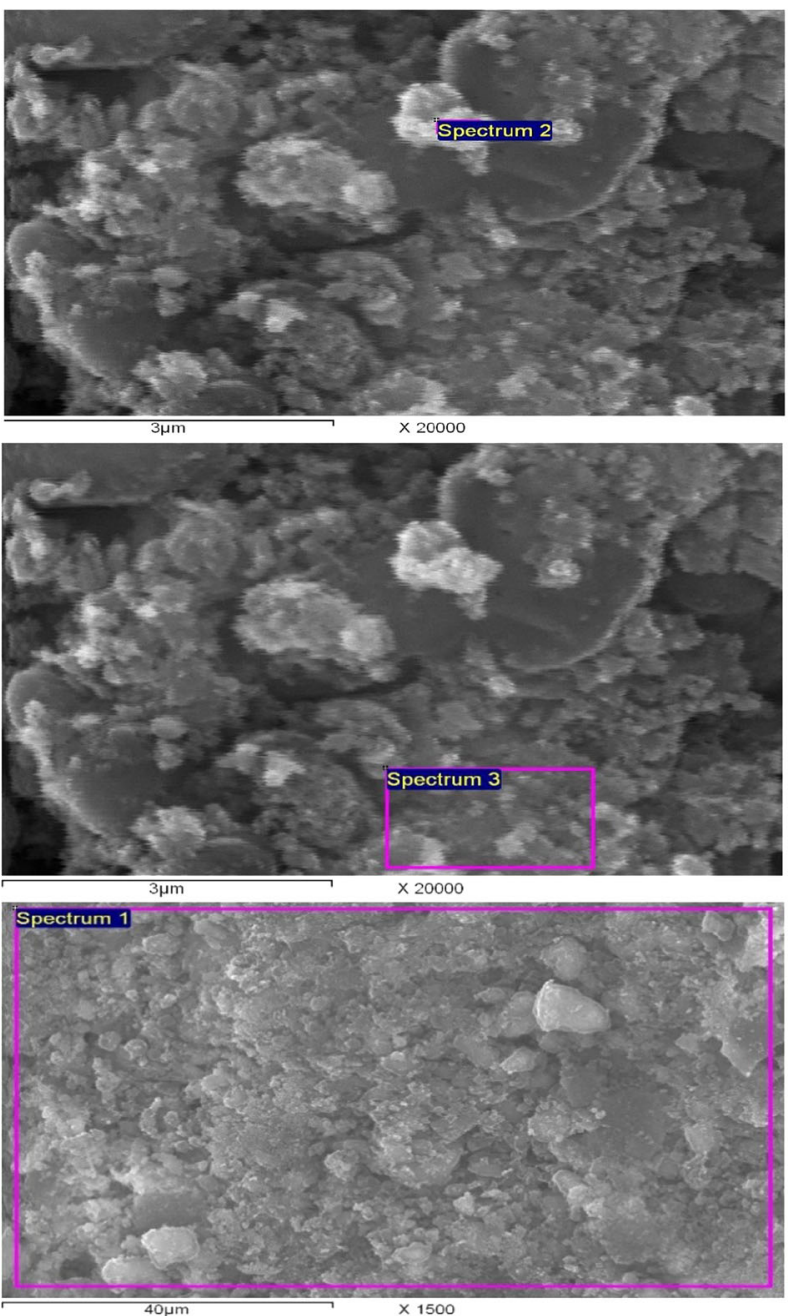
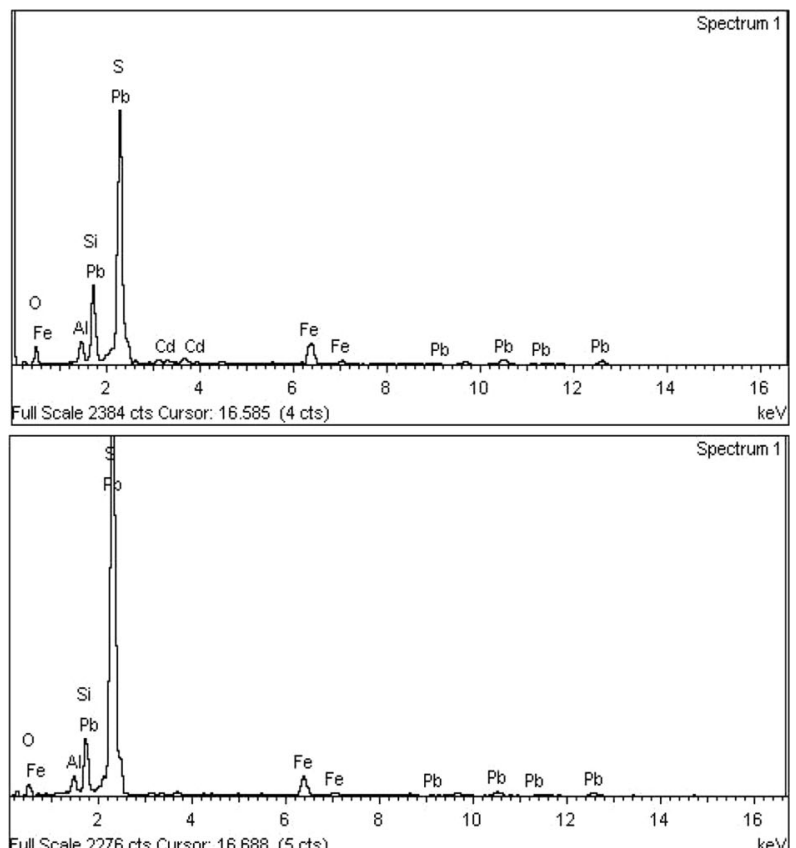

Full Scale $2276 \mathrm{cts}$ Cursor: $16.688(5 \mathrm{cts})$
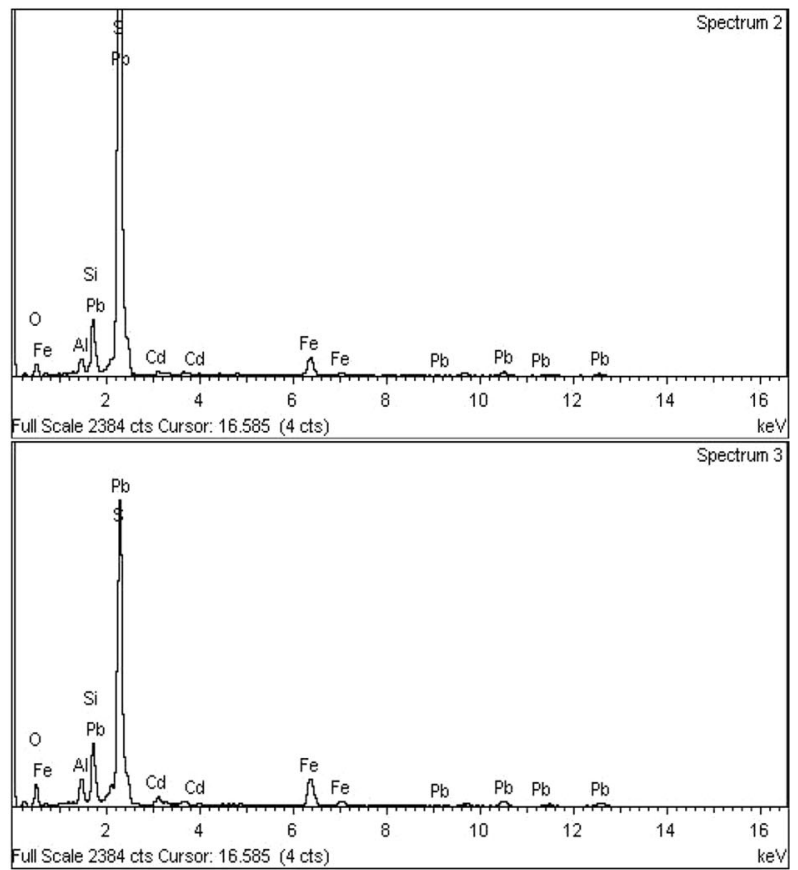

Eull Scale $2384 \mathrm{cts}$ Cursor: 16.585 ( $4 \mathrm{cts}$ ) $\mathrm{keV}$

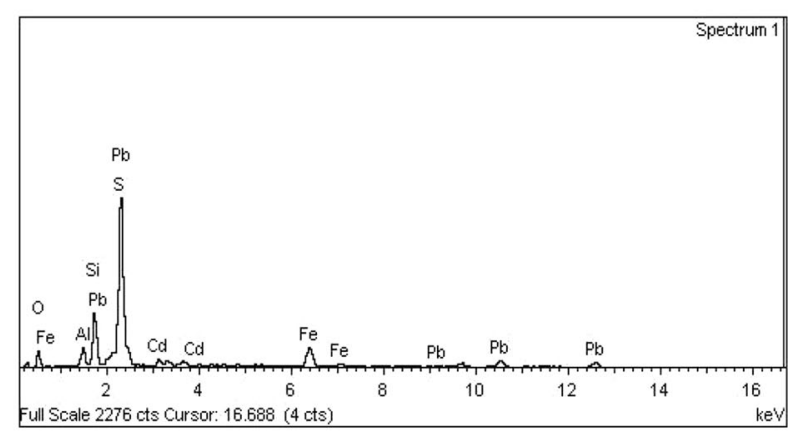


4Fig. 7 The morphology and composition of the soil samples, which have $\mathrm{Cd}, \mathrm{Fe}$ and $\mathrm{Pb}$ examined by scanning electron microscopy (SEM) images and XRD

content (Table 2). Samples in the small OM group contain particles composed of $\mathrm{Si}, \mathrm{Al}, \mathrm{Fe}$ and small amounts of $\mathrm{K}$ and $\mathrm{Ca}$. As the $\mathrm{OM}$ content increases, agglomerates of particles, characteristics of SEM (Méndez et al. 2009), have been identified. Samples in the large OM group have more compact and uniform aggregates (Fig. 7). They are formed of irregularly shaped particles with rounded edges. The XRD shows that the particles contain, together with $\mathrm{Mg}, \mathrm{Si}, \mathrm{Al}, \mathrm{Fe}$ and $\mathrm{K}$, elements from soil heavy metals such as $\mathrm{Cd}$ and $\mathrm{Pb}$, which are visible in Fig. 7.

Calcium might result from calcite $\left(\mathrm{CaCO}_{3}\right)$ in the samples. The presence of microaggregates $(<250 \mu \mathrm{m})$ is visible in SEM images (Fig. 7). Aggregation is generally facilitated by $\mathrm{CaCO}_{3}$ and clays (Six et al. 2002), which the chemical analysis showed were both present in the samples. The high $\mathrm{pH}$ observed could also mean the presence of cations, such as $\mathrm{Ca}^{2+}$, which form bridges between clay and OM (Bronick and Lal 2005).

\section{Conclusion}

VNIR-SWIR spectroscopy is a straightforward and nondestructive analytical method that can be utilized to predict heavy metals, which are spectrally feature-less. Large concentrations of heavy metals can be predicted using reflectance spectroscopy. Heavy metal elements cannot be identified with reflectance spectroscopy at concentrations under $1000 \mathrm{mg} \mathrm{kg}^{-1}$. Therefore, it is harder to determine small concentrations of heavy metals in soils of Bahr El Baqar region. Organic matter masks spectral signatures, making it difficult to identify metal quantities at these wavelengths. The fingerprint region of 538, 578, 630, 870, 1900,2240 , and $2376 \mathrm{~nm}$ is very useful in recognizing small differences in the heavy metals of Bahr El Baqar region. A close match between several spectra in this fingerprint region constitutes strong evidence for the identity of heavy metals in the spectra. Several heavy metals (Fe, $\mathrm{Cu}, \mathrm{Cd}$, and $\mathrm{Pb}$ ) have sharp bands between these regions. The majority of single bonds give rise to absorption bands within these frequencies and, due to similarities in their energies, strong interactions occur between neighboring bonds. PLSR is able to some extent to model heavy metals with laboratory spectra parameters. It was possible to predict heavy metals with moderate accuracy. The best coefficients of determination $\left(R^{2}\right)$ between the real and predicted contents were for $\mathrm{Mn}, 0.62 ; \mathrm{Pb}, 0.66 ; \mathrm{Zn}, 0.66$; $\mathrm{Ni}, 0.69$; and $\mathrm{Cu}, 0.60 . \mathrm{Mn}, \mathrm{Pb}, \mathrm{Ni}, \mathrm{Cu}$, and $\mathrm{Zn}$ were successfully predicted using partial least squares regression, PLSR. To increase prediction accuracy, specific wavelengths were used with OM, iron oxides, and clay. Correlation analysis revealed that most important wavelengths for prediction could be attributed to the absorption features of OM, clay and iron oxides. Group I has $\mathrm{Cr}$, which is related to iron oxides, clays, and organic matter. Group II has Ni and Mn, which is related to iron oxides and clays. Group III has $\mathrm{Cu}$, which is related to iron oxides. Group V has Co, which is related to clays. Group IV has $\mathrm{Cd}$ and $\mathrm{Pb}$, which is related to organic matter.

Due to the interference effects of organic matter and low heavy metal concentration, the selection of the most sensitive original spectral bands still did not result in highly accurate prediction. Therefore, it is important to predict heavy metals through OM, iron oxides, or clays first. To identify the specific wavelengths for prediction of the studied heavy metals, the regression coefficient with OM, $\mathrm{Al}_{2} \mathrm{O}_{3}$, and $\mathrm{Fe}_{2} \mathrm{O}_{3}$ were used. The most significant peaks for $\mathrm{Zn}$ prediction are found in the wavelengths of 430, 570, and $1700 \mathrm{~nm}$; for $\mathrm{Cu}$ prediction at 538, 1259, 1500, and $2184 \mathrm{~nm}$; for $\mathrm{Pb}$ significant peaks are at 440, 578, 915, and $1894 \mathrm{~nm}$; for $\mathrm{Cr}$ at 860, 1001, and $2376 \mathrm{~nm}$; for $\mathrm{Ni}$ at 870, 909, and $2240 \mathrm{~nm}$; for $\mathrm{Cd}$ at 630 and $1270 \mathrm{~nm}$; for Co at 1900 and $2300 \mathrm{~nm}$.

These results indicate that it is possible to predict heavy metals in soils using the rapid and economic reflectance spectroscopy. For future investigations, hyperspectral sensor may be useful to optimize the estimation of heavy metals content at large scale. Future research likewise will focus on definitely establishing whether $\mathrm{Cd}$ and $\mathrm{Pb}$ contamination in soils can be assessed directly or indirectly in the VNIR-SWIR region using artificially soils spiked with $\mathrm{Pb}$ in the range 50-10,000 ppm. An urgent research need in Egypt is the development of soil spectral libraries that will improve the predictive ability of VNIR-SWIR spectroscopy for soil minerals and other soil attributes whatever the soil type. Coupling spectral libraries with other diffuse reflectance measurements of soils, such as mid-infrared reflectance spectra, will probably be the next step towards spectral sensing of soil heavy metals.

Acknowledgements The author would like to thank the late Dr. A. Abd El Razek for her assistance in the fieldwork and data collection.

\section{References}

Barnes RJ, Dhanoa MS, Lister SJ (1989) Standard normal variate transformation and de-trending of near-infrared diffuse reflectance spectra. Appl Spectrosc 43(5):772-777

Bray J, Rossel R, McBratney A (2009) Diagnostic screening of urban soil contaminants using diffuse reflectance spectroscopy. Aust J Soil Res 47:433-442 
Bronick C, Lal R (2005) Soil structure and management: a review. Geoderma 124:3-22

Brown DJ, Shepherd KD, Walsh MG, Dewayne Mays M, Reinsch TG (2006) Global soil characterization with VNIR diffuse reflectance spectroscopy. Geoderma 132(3-4):273-290

Choe E, Meer F, Ruitenbeek F, Werff H, De Smeth B, Kim K (2008) Mapping of heavy metal pollution in stream sediments using combined geochemistry, field spectroscopy, and hyperspectral remote sensing: a case study of the Rodalquilar mining area, SE Spain. Remote Sens Environ 112:3222-3233

Choe E, Meer F, Ruitenbeek F, Werff H, De Smeth B, Kim K (2009) Qualitative analysis and mapping of heavy metals in an abandoned $\mathrm{Au}-\mathrm{Ag}$ mine area using NIR spectroscopy. Environ Geol 58(3):477-482

Conforti M, Raffaele F, Giorgio M, Tommaso C, Gabriele B (2013) Potentiality of laboratory visible and near infrared spectroscopy for determining clay content in forest soils: a case study from high forest beech (Fagus Sylvatica) in Calabria (Southern Italy). Environ Qual 11:49-64

Conzález-Martín I, Hernández-Hierro JM, Barros-Ferreiro N, Cordón C, García-Villanova RJ (2007) Use of NIRS technology with a remote reflectance fibre-optic probe for predicting major components in bee pollen. Talanta 72:998-1003

Ertlen D, Schwartz D, Trautmann M, Webster R, Brunet D (2010) Discriminating between organic matter in soil from grass and forest by near-infrared spectroscopy. Eur J Soil Sci 61:207-216

Gannouni S, Rebai N, Abdeljaoued S (2012) A spectroscopic approach to assess heavy metals contents of the mine waste of Jalta and Bougrine in the North of Tunisia. J Geograph Inf Syst $4: 242-253$

Gaydon JW, Glass H, Pascoe R (2009) Method for near infrared sensor-based sorting of a copper ore. J Near Infrared Spectrosc 17:177-194

Gholizadeh A, Boruvka L, Saberioon M, Kozak J, Vasat R, Nemecek K (2015a) Comparing different data preprocessing methods for monitoring soil heavy metals based on soil spectral features. Soil Water Res 10(4):218-227

Gholizadeh A, Borůvka Luboš, Vašát R, Saberioon M, Klement A, Kratina J, Tejnecký V, Drábek O (2015b) Estimation of potentially toxic elements contamination in anthropogenic soils on a brown coal mining dumpsite by reflectance spectroscopy: a case study. PLoS One 10(2):e0117457

Ji J, Song Y, Yuan X, Yang Z (2010) Diffuse reflectance spectroscopy study of heavy metals in agricultural soils of the Changjiang River Delta, China. In: 19th World Congress of Soil Science, Soil Solutions for a Changing World, Brisbane

Kemper T, Sommer S (2002) Estimate of heavy metal contamination in soils after a mining accident using reflectance spectroscopy. Environ Sci Technol 36:2742-2747

Kemper T, Sommer S (2003) Mapping and monitoring of residual heavy metal contamination and acidification risk after the Aznalcóllar mining accident (Andalusia, Spain) using field and airborne hyperspectral data. In: The 3rd EARSeL Workshop on Imaging Spectroscopy, Herrsching

Malley DF, Williams PC (1997) Use of near-infrared reflectance spectroscopy in prediction of heavy metals in freshwater sediment by their association with or-ganic matter. Environ Sci Technol 31(12):3461-3467. doi:10.1021/es970214p

Malley DF, Martin PD, Ben-Dor E (2004) Application in analysis of soils. In: Roberts CA (ed) Near-infrared spectroscopy in agriculture. Agronomy Monograph 44 American Society of Agronomy, Crop Science Society of America, Soil Science Society of America, Madison, WI, USA, pp 729-784

Martens H, Næs T (1989) Multivariate calibration. Wiley, New York
Martens H, Jensen SA, Geladi P (1983) Multivariate linearity transformations for near infrared reflectance spectroscopy. In: Christie OHJ (ed) Proc Nordic Symp Applied Statistics, Stokkland Forlag, Stavanger, Norway, pp 205-234

Méndez A, Fidalgo J, Guerrero F, Gascó G (2009) Characterization and pyrolysis behaviour of different paper mill waste materials. J Anal Appl Pyrol 86:66-73

Minasny B, Tranter G, McBratney A, Brough D, Murphy B (2009) Regional transferability of mid-infrared diffuse reflectance spectroscopic prediction for soil chemical properties. Geoderma 153:155-162

Morón A, Cozzolino D (2003) Exploring the use of near infrared reflectance spectroscopy to study physical properties and microelements in soils. J Near Infrared Spectrosc 11:145-154

Moros J, de Vallejuelo SFO, Gredilla A, de Diego A, Madariaga JM, Garrigues S, de la Guardia M (2009) Use of reflectance infrared spectroscopy for monitoring the metal content of the estuarine sediments of the Nerbioi-Ibaizabal River (Metropolitan Bilbao, Bay of Biscay, Basque Country). Environ Sci Technol 43:9314-9320

Nicolaï BM, Beullens K, Bobelyn E, Peirs A, Saeys W, Theron KI, Lammertyn J (2007) Nondestructive measurement of fruit and vegetable quality by means of NIR spectroscopy: a review. Postharvest Biol Technol 46(2):99-118

Omran ESE (2016) Environmental modelling of heavy metals using pollution indices and multivariate techniques in the soils of Bahr El Baqar, Egypt. Modeling Earth Syst Environ 2(3):1-17. doi:10. 1007/s40808-016-0178-7

Omran ESE, Abd El Razek AA (2012) Mapping and screening risk assessment of heavy metals concentrations in soils of the Bahr El-Baker Region, Egypt. J Soil Sci Environ Manag 6(7):182-195

Pandit M, Filippelli M, Li L (2010) Estimation of heavy-metal contamination in soil using reflectance spectroscopy and partial least-squares regression. Int J Remote Sens 31(15):4111-4123

Park J, Shin W (2006) Immobilization of Pb contamined soil using modified clay. Water Pract Technol 1:1-10

Peng Y, Knadel M, Gislum R, Deng F, Norgaard T, Wollesen de Jonge L, Moldrup P, Humlekrog Greve M (2013) Predicting soil organic carbon at field scale using a national soil spectral library. J Near Infrared Spectrosc 21:213-222

Pirie A, Singh B, Islam K (2005) Ultra-violet, visible, near-infrared, and mid-infrared diffuse reflectance spectroscopic techniques to predict several soil properties. Aust J Soil Res 43(6):713-721

Ren HY, Zhuang DF, Singh AN, Pan J, Qiu DS, Shi RH (2009) Estimation of $\mathrm{As}$ and $\mathrm{Cu}$ contamination in agricultural soils around a mining area by reflectance spectroscopy: a case study. Pedosphere 19(6):719-726

Rinnan A, van den Berg F, Engelsen SB (2009) Review of the most common pre-processing techniques for near-infrared spectra. Trends Anal Chem 28:1201-1222

Rizzo R, Demattê JAM, da Silva TF (2014) Using numerical classification of profiles based on Vis-Nir spectra to distinguish soils from the Piracicaba Region, Brazil. Braz R Bras Ci Solo $38: 372-385$

Saad AK (1997) Environmental hydrogeologic impacts groundwater withdrawal in the eastern Nile Delta region with emphasis on groundwater pollution potential. $\mathrm{Ph} \mathrm{D}$ Thesis, Institute of Environmental Studies Ain Shams Univ, pp 232

Sakizadeh M, Mirzaei R, Ghorbani H (2015) The Extent and Prediction of Heavy Metal Pollution in Soils of Shahrood and Damghan, Iran. Bull Environ Contam Toxicol 95(6):770-776. doi:10.1007/s00128-015-1632-3

Schwartz G, Eshel G, Ben-Dor E (2012) Reflectance spectroscopy as a rapid tool for monitoring contaminated soil. Porter School of environmental studies, Tel Aviv University PhD thesis 
Siebielec G, McCarty GW, Stuczynski TI, Reeves JB (2004) Nearand mid-infrared diffuse reflectance spectroscopy for measuring soil metal content. J Environ Qual 33(6):2056-2069

Six J, Feller C, Denef K, Ogle S, de Moraes Sa J (2002) Soil organic matter, biota and aggregation in temperate and tropical soils effects of no-tillage. Agron, EDP Sci 22(7-8):755-775

Stenberg B, Viscarra Rossel R, Mouazen AM, Wetterlind J (2010) Visible and near infrared spectroscopy in soil science. Adv Agron 107:163-215

Summers D (2009) Discriminating and Mapping Soil Variability with Hyperspectral Reflectance Data. Faculty of science, School of earth and environmental science, Adelaide UniversityPhD thesis

Tekin Y, Tumsavas Z, Mouazen A (2012) Effect of moisture content on prediction of organic carbon and $\mathrm{pH}$ using visible and near infrared spectroscopy. Soil Sci Soc Am J 76(1):188-198

Todorova M, Mouazen AM, Lange H, Atanassova S (2014) Potential of near-infrared spectroscopy for measurement of heavy metals in soil as affected by calibration set size. Water Air Soil Pollut 225:2036. doi:10.1007/s11270-014-2036-4

Umetrics (2002) User Guide to SIMCA P. Umetrics (ed), Umetrics

Vasques GM, Grunwald S, Sickman O (2008) Comparison of multivariate methods for inferential modeling of soil carbon using visible/near-infrared spectra. Geoderma 146:14-25

Viscarra Rossel RA (2008) The soil spectroscopy group and the development of a global spectral library. In: 3rd global workshop on digital soil mapping. Utah State University, Logan, Utah, 30 September-3 October 2008

Vohland M, Bossung C, Frund H (2009) A spectroscopic approach to assess trace-heavy metal contents in contaminated floodplain soils via spectrally active soil components. Plant Nutr Soil Sci 172(2):201-209

Walkley A, Black A (1934) An examination of the Degtjareff method for determining soil organic matter, and a proposed modification of the chromic acid titration method. Soil Sci Aoc Am J 37:29-38

Wetterlind J, Bo S, Jonsson A (2008) Near infrared reflectance spectroscopy compared with soil clay and organic matter content for estimating within-field variation in $\mathrm{N}$ uptake in cereals. Plant Soil 302(1-2):317-327

Wetterlind J, Stenberg B, Viscarra Rossel, Raphael A (2013) Soil analysis using visible and near infrared spectroscopy. In: FJM Maathuis (ed) Plant mineral nutrients: methods and protocols. Humana Press, Springer, New York, pp 95-107 (Published in serie: Methods in molecular biology, $\mathrm{nr}$ 953)

Winkelmann KH (2005) On the applicability of imaging spectrometry for the detection and investigation of contaminated sites with particular consideration given to the detection of fuel hydrocarbon contaminants in soil. Unpublished PhD Thesis Brandenburg University of Technology

Wu Y, Chen J, Wu X, Tian Q (2005) Possibilities of reflectance spectroscopy for the assessment of contaminant elements in suburban soils. Appl Geochem 20:1051-1059

Wu Y, Chen J, Ji J, Gong P, Liao Q, Tian Q, Ma H (2007) A mechanism study of reflectance spectroscopy for investigating heavy metals in soils. Soil Sci Soc Am J 71:918-926

Wu C, Jacobson A, Laba M, Baveye P (2009) Accounting for surface roughness effects in the near-infrared reflectance sensing of soils. Geoderma 152:171-180. doi:10.1016/j.geoderma.2009.06. 002

Yaolin L, Wei L, Guofeng W, Xinguo X (2011) Feasibility of estimating heavy metal contaminations in floodplain soils using laboratory-based hyperspectral data-a case study along Le'an River, China. Geo-spatial Information Science 14(1):10-16

Zhang Z, Wen J, Zhao D (2010) Band selection method for retrieving soil lead content with hyperspectral remote sensing data. The Society of Photo-Optical Instrumentation Engineers (SPIE) 7831 